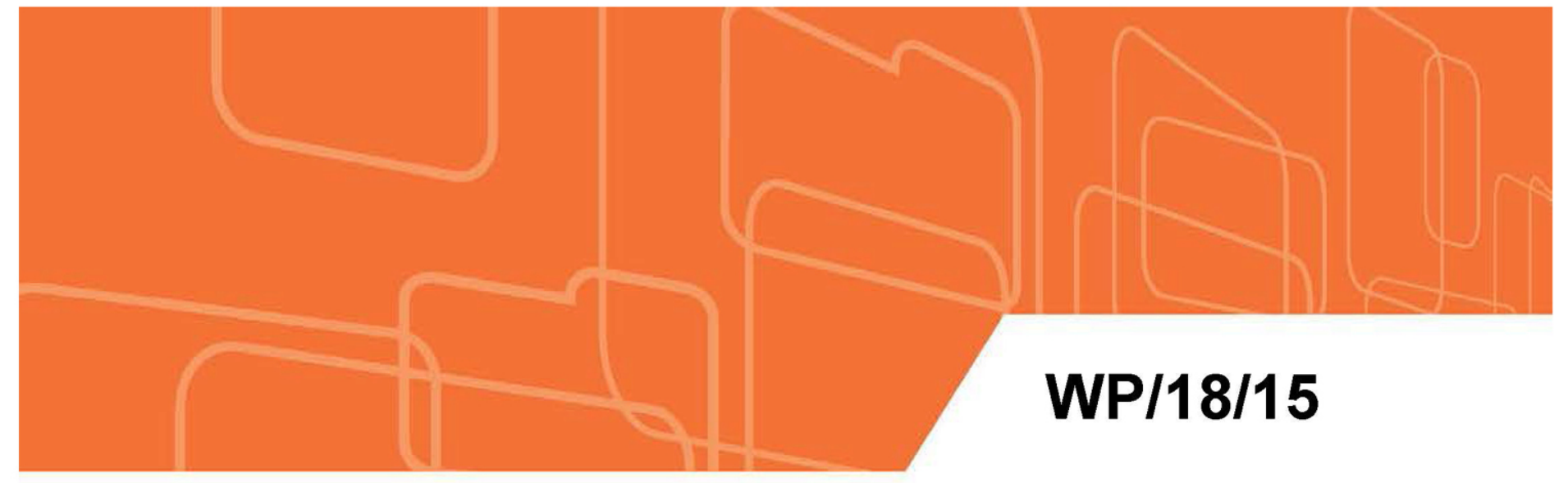

IMF Working Paper

\title{
Can Countries Manage Their Financial Conditions Amid Globalization?
}

by Nicolas Arregui, Selim Elekdag, Gaston Gelos, Romain Lafarguette, and Dulani Seneviratne

IMF Working Papers describe research in progress by the author(s) and are published to elicit comments and to encourage debate. The views expressed in IMF Working Papers are those of the author(s) and do not necessarily represent the views of the IMF, its Executive Board, or IMF management.

$$
\text { I N T ER N A T I O N A L M O N E T A R Y F U N D }
$$




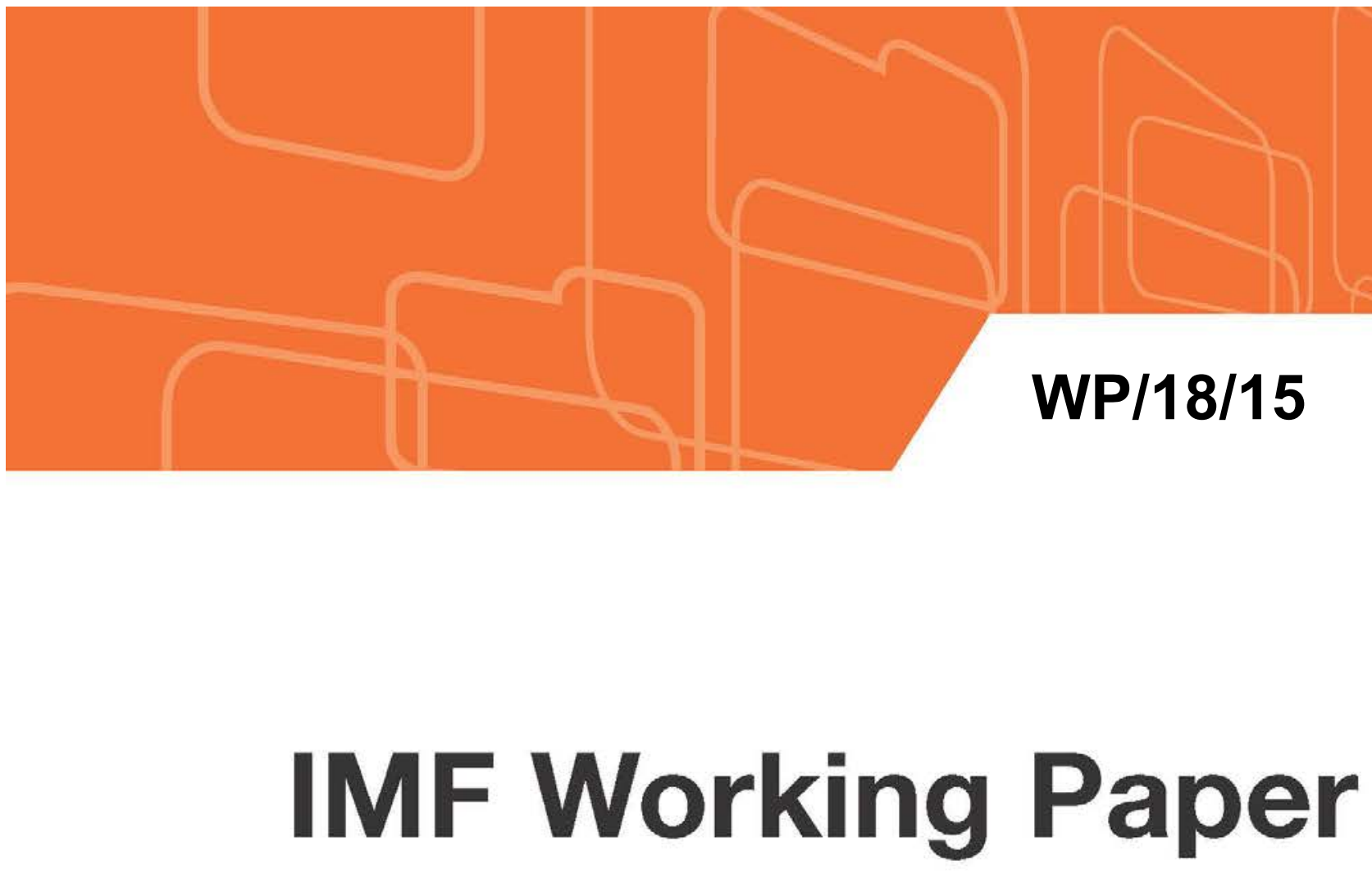

\section{Can Countries Manage Their Financial Conditions Amid Globalization?}

by Nicolas Arregui, Selim Elekdag, Gaston Gelos, Romain Lafarguette, and Dulani Seneviratne

IMF Working Papers describe research in progress by the author(s) and are published to elicit comments and to encourage debate. The views expressed in IMF Working Papers are those of the author(s) and do not necessarily represent the views of the IMF, its Executive Board, or IMF management. 


\title{
IMF Working Paper
}

Monetary and Capital Markets Department

\section{Can Countries Manage Their Financial Conditions Amid Globalization?}

Prepared by Nicolas Arregui, Selim Elekdag, Gaston Gelos, Romain Lafarguette, and Dulani Seneviratne ${ }^{1}$

January 2018

\section{IMF Working Papers describe research in progress by the author(s) and are published to elicit comments and to encourage debate. The views expressed in IMF Working Papers are those of the author(s) and do not necessarily represent the views of the IMF, its Executive Board, or IMF management.}

\begin{abstract}
This paper examines the evolving importance of common global components underlying domestic financial conditions. It develops financial conditions indices (FCIs) that make it possible to compare a large set of advanced and emerging market economies. It finds that a common component, "global financial conditions," accounts for about 20 percent to 40 percent of the variation in countries' domestic FCIs, with notable heterogeneity across countries. Its importance, however, does not seem to have increased markedly over the past two decades. Global financial conditions loom large, but evidence suggests that, on average, countries still appear to hold considerable sway over their own financial conditionsspecifically, through monetary policy. Nevertheless, the rapid speed at which foreign shocks affect domestic financial conditions may also make it difficult to react in a timely and effective manner, if deemed necessary.
\end{abstract}

JEL Classification Numbers: E44, E5, F3, F4

Keywords: Financial conditions, monetary policy, international policy transmission Author’s E-Mail Address: NArregui@imf.org, SElekdag@imf.org, GGelos@imf.org, RLafarguette@imf.org, DSeneviratne@imf.org

\footnotetext{
${ }^{1}$ The views expressed in this working draft are those of the authors and do not necessarily represent the views of the IMF, its Executive Board, or IMF management. This paper is background to Chapter 3 of the April 2017 GFSR, "Are Countries Losing Control of Domestic Financial Conditions?” (IMF 2017).
} 
Abstract .$\underline{2}$

I. Introduction $\underline{5}$

II. An Overview of Financial Conditions

A. Financial Conditions: Main Concepts and a Selected Review of the Literature ....... $\frac{7}{7}$

B. The Transmission of Financial Conditions Across Countries

C. Constructing Financial Conditions Indices Across Advanced and Emerging Market Economies

III. Financial Conditions around the World $\underline{12}$

A. Financial Conditions Indices: Selected Countries ..........................................12

B. The Evolution of Financial Conditions Around the World................................... 14

C. Country Characteristics and Sensitivity to Global Financial Conditions.................19

IV. Can Countries Manage Domestic Financial Conditions Amid Global Financial Integration? .$\underline{25}$

A. Transmission of Global Financial and Domestic Monetary Policy Shocks to

Domestic FCIs .$\underline{25}$

C. Recognizing Country Heterogeneity.... $\underline{32}$

D. A More Refined Approach to Identifying Monetary Policy Shocks ......................

E. The Influence of Global Financial Conditions: 2001-07 versus 2010-16..............

V. Conclusion .$\underline{35}$

Tables

1. Summary: Determinants of the Sensitivity of Domestic FCIs .$\underline{21}$

2. Determinants of Sensitivity to Global Financial Conditions .$\underline{23}$

3. Robustness: Determinants of Sensitivity to Global Financial Conditions..... .$\underline{24}$

4. Summary: Panel VAR Robustness: Impulse Response of Domestic FCI to......................... .$\frac{27}{28}$

5. Summary: Individual Country VAR Robustness Impulse Response .... .28

6. Summary Panel VAR Robustness: Share of Domestic FCI Variation .............................. $\underline{30}$

7. Summary: Individual Country VAR Robustness: Share of Domestic FCI ........................

Figures

1. United States: Financial Conditions Indices, 1991-2016 ........................................13

2. Selected Advanced and Emerging Market Economies..................................................14

3. Three-Factor Model Based on Financial Conditions Index, 1995-2016 ..........................15

4. Single Factor Versus Principal Component Analysis, 1995-2015 …............................16

5. Variance Accounted for by One and Three Factor Models .........................................17

6. Variance Attributable to Global Conditions, 1995-2016 ….......................................18

7. Robustness: Attributable to Global Financial Conditions, 1995-2016 ............................18 
8. Robustness: Variance Attributable to Global Financial Conditions, ................................ 19

9. Response of Domestic Financial Conditions to Shocks ...........................................26

10. Share of Domestic Financial Conditions Index Fluctuations Attributable to ...................29

11. Share of Domestic Financial Conditions Index Fluctuations Attributable to .....................32

12. Selected Advanced Economies: Response of Financial Conditions Index...................... $\underline{34}$

13. Share of Domestic Financial Index Fluctuations Attributable to Global Financial............

Appendix Tables

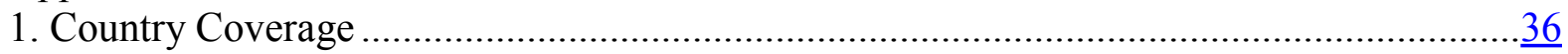

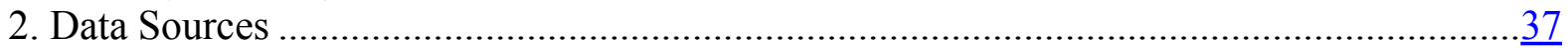

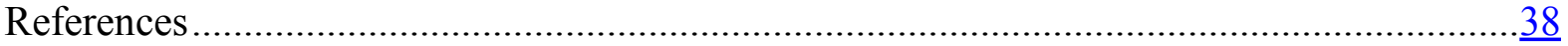




\section{INTRODUCTION}

To what extent can individual countries steer domestic financial conditions in a globally integrated financial system? This question has been attracting increased interest recently and continues to be hotly debated in policy and academic circles alike.

One side of the debate is underpinned by the concern that the greater potential impact of global factors on domestic asset prices and credit leaves policymakers little room to influence their countries' financial conditions in line with domestic objectives. For instance, Rey (2016) argues that in a world of freely flowing capital, United States (U.S.). monetary policy shocks spill over and affect domestic financial conditions - even in economies with flexible exchange rates and large financial markets. Likewise, Rey (2013) concludes that fluctuating exchange rates cannot insulate economies from the global financial cycle when capital is mobile. Rey contends that the Mundell-Fleming trilemma has morphed into a dilemma: independent monetary policy is possible only with restricted capital mobility, regardless of the exchange rate regime. On the other side of the debate, Kamin (2010), Obstfeld (2015), Klein and Shambaugh (2015), and Obstfeld, Ostry, and Qureshi (2017), for example, argue that exchange rate flexibility does allow for at least some degree of monetary autonomy. Relatedly, Disyatat and Rungcharoenkitkul (2016), and, to a lesser extent, IMF (2017) conclude that policymakers retain considerable sway over domestic financial conditions.

This paper focuses on financial conditions, which can be thought of as broadly reflecting how easy it is to obtain financing. Going beyond short-term interest rates, financial conditions summarize information about the price and nonprice costs (such as terms and conditions) of credit for various agents in the economy.

Financial conditions play a key role in the conduct of monetary policy, which "works its magic through its effect on financial conditions" (Dudley 2010). Monetary policy largely seeks to influence inflation and output through its effects on financial market variables (including asset prices, bank credit volumes, collateral valuations, and term premiums), along with direct effects through policy rates. ${ }^{2}$

A higher comovement of domestic financial conditions across countries is not per se represent sufficient evidence for a loss in national policy autonomy. Such correlations may be a natural reflection of comovements in fundamentals because of greater trade and financial integration and could, therefore, be optimal from a domestic standpoint. Of course, as countries become more financially integrated, policymakers must respond to a broader range of developments, complicating their task. But, again, this alone does not constitute a loss in policy autonomy in steering domestic financial conditions (Disyatat and Rungcharoenkitkul 2016). On the other hand, global financial integration may indeed reduce policymakers' room for maneuver, for example by weakening the transmission channels of domestic monetary policy or by diminishing the impact of prudential policies. This situation

\footnotetext{
${ }^{2}$ Furthermore, measures of financial conditions have been shown to be reliable predictors of economic activity (Hatzius and others 2010; Gilchrist and Zakrajšek 2012; Koop and Korobilis 2014, among others). Indices of financial conditions have also proved useful in predicting downside risks to GDP growth (Adrian, Boyarchenko, and Giannone 2016; IMF 2017) and helpful in detecting the buildup of financial vulnerabilities (Adrian and Liang 2016).
} 
would also expose countries to shocks that are unwarranted by economic fundamentals, such as shifts in investor sentiment.

This paper examines the importance of common global components underlying domestic financial conditions, the evolving role of these global factors over time, and their key drivers. It explores country characteristics that influence the extent to which domestic financial conditions move with global factors and the ability of monetary policy to influence domestic financial conditions. For this purpose, it develops new financial conditions indices (FCIs) that are purged of macroeconomic factors and comparable across a large set of advanced and emerging market economies - a contribution to the literature in its own right.

The main results of the paper can be summarized as follows:

- A single factor, "global financial conditions," accounts for a large share of variation in domestic financial conditions around the world. This factor moves in tandem with the U.S. FCIs and measures of global risk, such as the VIX.

- There is no conclusive evidence, however, that this global factor has gained significant influence over the past two decades.

- Financial linkages (such as cross-country investments) are the most reliable indicator of global financial conditions' influence on local FCIs. At the same time, greater financial development can reduce the sensitivity of domestic FCIs to global financial shocks.

- About 20 to 40 percent of the variation in domestic FCIs across countries can be attributed to global financial conditions, with domestic factors accounting for the rest. However, the importance of global financial shocks for domestic financial conditions varies notably across countries. Importantly, domestic monetary policy shocks account for about 15 percent of the variation across countries with flexible exchange rates, suggesting that amid exposure to external factors, changes in the monetary policy stance can still matter for domestic financial conditions.

Overall, even with a sizable impact from global financial shocks, evidence suggests that, on average, countries appear to be able to influence their own financial conditions. In particular, the analysis indicates that they generally have scope to use monetary policy. However, given that local financial conditions react more rapidly to global financial shocks than to changes in domestic policy rates, timely policy responses may often be difficult.

The rest of the paper is structured as follows. The next section reviews the literature and key concepts pertaining to financial conditions as well as explains how the financial conditions indices (FCIs) developed in this paper are constructed. Section III begins by presenting key stylized facts about financial conditions around the world. It then discusses how various country characteristics are related to the sensitivity of domestic FCIs to global financial shocks. Section IV focuses on quantifying the relative share of fluctuations in countries' domestic financial conditions explained by global financial and domestic monetary policy shocks. The final section concludes. 


\section{An Overview of Financial Conditions}

\section{A. Financial Conditions: Main Concepts and a Selected Review of the Literature}

Financial conditions generally refer to the ease of obtaining financing. The literature, however, offers several complementary definitions. For instance, Hatzius and others (2010) define them as the current state of financial variables that influence economic behavior and thereby the future of the economy, while Carlson, Lewis, and Nelson (2012) connect them to price and nonprice costs of credit. In the same spirit, this paper focuses on a notion of domestic financial conditions that seeks to gauge the costs, conditions, and availability of domestic funds to the local economy. In addition to interest rates and asset price valuations, financial conditions are influenced by risk appetite and, for example, agents' willingness to hold illiquid assets.

Financial conditions play a central role in the transmission of monetary policy to the broader economy. In particular, monetary policy influences the rest of the economy largely by altering financial conditions, and the transmission channels can be classified into two broad categories. The first comprises the "traditional" or New Keynesian channels of monetary policy. The emphasis is on changes in (short-term) policy rates and how expectations about those changes alter longer-term rates and thereby consumption and investment decisions. Effects on trade through exchange rate movements also belong to the list of traditional channels. The second category predominantly comprises imperfections in credit supply arising from institutional constraints on financial intermediaries and from informational asymmetries (Boivin, Kiley, and Mishkin 2010). Examples include the balance sheet channel (Bernanke and Gertler 1989; Kiyotaki and Moore 1997), the bank capital channel (Van den Heuvel 2002), and the risk-taking channels (Adrian and Shin 2011; Adrian and Boyarchenko 2012), as discussed in greater detail in Adrian and Liang (2016).

Many of these "nontraditional" monetary transmission channels feature both incomplete markets and heterogeneous agents, which leads to differences in the pricing of risk over time. As a result, the risk-free rate is not an adequate statistic for funding costs or for assessing the impact of monetary policy on the real economy. ${ }^{3}$ FCIs thus aim to distill information from a broad array of financial variables - including measures of risk taking and various kinds of financial frictions - ideally capturing the importance of credit constraints and the magnitude of external financing premiums. FCIs can only capture some measure of average funding costs, although different agents may face large variations in funding costs and conditions. Naturally, as financial systems evolve, the most relevant variables for tracking financial conditions may change.

\footnotetext{
${ }^{3}$ As underscored by Dudley (2010), financial conditions are explicitly taken into account in the conduct of monetary policy. In the United States, he notes that this is evident in the transcripts of the Federal Open Market Committee meetings and minutes going back more than a decade. Even before the global financial crisis, Bernanke (2007) highlighted links between financial conditions and growth. More recently, Yellen (2016) drew attention to the relevance of financial conditions for the economic outlook and the stance of monetary policy.
} 
Empirically, measures of financial conditions can be more helpful in predicting economic activity than indicators of current and past real economic activity. Studies including Hatzius and others (2010) and Koop and Korobilis (2014) argue that FCIs are good predictors of future economic activity. Likewise, Adrian, Boyarchenko, and Giannone (2016) show that FCIs are particularly useful in flagging future economic contractions.

Financial conditions are driven only partly by policy. Changes in uncertainty about the exposures of major financial players, shocks to the net worth of borrowers not triggered by policy actions, runs on financial institutions, changes in risk perception, and shifts in investor sentiment triggered by idiosyncratic events can all influence access to funding in an economy.

\section{B. The Transmission of Financial Conditions Across Countries}

A central principle guiding monetary policy in open economies is the so-called MundellFleming "trilemma." It states that policymakers can seek to achieve only two out of the three following objectives: (1) fixed exchange rates, (2) free international capital mobility, and (3) monetary autonomy. Flexible exchange rates, on the other hand, can insulate an economy from external financial shocks.

However, in reality, financial conditions can be transmitted across countries in ways that may not be fully offset by movements in exchange rates (Obstfeld 2015). In fact, exchange rate movements themselves typically induce changes in financial conditions in small open economies, potentially amplifying external shocks (Kearns and Patel 2016). Transmission mechanisms include changes in credit volumes and other types of capital flows, and comovements in risk premiums, which can affect collateral valuation and thereby borrowing constraints (Obstfeld 2015).

If countries cannot fully insulate themselves from external financial shocks, global financial integration can complicate the management of domestic financial conditions in at least two distinct ways. First, as countries integrate more into the global economy, policymakers may need to take external factors into greater consideration when pursuing domestic objectives. However, this complication does not, by itself, imply that countries lose their ability to steer their domestic financial conditions. Second, global financial integration may indeed make it harder for domestic policymakers to control domestic financial conditions-for example, by hampering the transmission of monetary policy or limiting the effectiveness of prudential policies. External financial shocks may affect local financial conditions abruptly, making it 
difficult to react in a timely and effective manner. ${ }^{4}$ In particular, the efficacy of financial stability policies can be weaker in an open economy (Schoenmaker 2013). ${ }^{5}$

Various studies suggest that financial conditions around the world are heavily influenced by global factors. Building on earlier work by Calvo, Leiderman, and Reinhart (1996), many studies emphasize the important role of global "push factors," such as the VIX, as drivers of financial variables (see, for example, Bruno and Shin 2013; IMF 2014a; Fratzscher 2012; Baskaya and others 2017). Miranda-Agrippino and Rey (2015) argue that prices of risky assets (such as equities and corporate bonds) across countries can be summarized by a single global factor, the "global financial cycle," which is driven by U.S. monetary policy shocks. Therefore, as argued by Rey (2016), U.S. monetary policy shocks spill over and affect domestic financial conditions even in inflation-targeting economies with large financial markets. Longstaff and others (2011) find that three factors account for more than 50 percent of the variation in credit default swap spreads across countries, and Adrian, Stackman, and Vogt (2016) estimate a highly significant price of risk that forecasts global stock and bond returns as a nonlinear function of the VIX. ${ }^{6}$

Evidence of global factors' greater influence, however, is not by itself proof that policymakers are losing control over domestic financial conditions. Financial conditions that move together across countries may be a natural reflection of comovement in fundamentals because of greater trade and financial integration and could, therefore, be optimal from a domestic standpoint. For example, for a globally integrated economy whose business cycle is highly correlated with the rest of the world, raising domestic interest rates in response to a rise in world interest rates may be the best decision from a domestic perspective.

But some changes in financial conditions have nothing to do with macroeconomic factors and may arise from financial frictions (including changes in investor sentiment, the effects of herd behavior, risk management constraints, or regulations). Conceptually, in an extreme case, if empirically domestic financial conditions were predominantly influenced by such spillovers not driven by fundamentals (and therefore likely to be undesirable), this would suggest a "lack of control" by policymakers. The reason is that policymakers will most likely attempt to counteract such shocks. Accordingly, if these non-fundamental-driven spillovers still featured prominently in domestic financial conditions, this would be an indication that policymakers do not have the tools to react in an effective or timely manner to offset them. Empirically, the distinction between fundamentals-driven versus other types of spillovers is not easy to derive (see Disyatat and Rungcharoenkitkul 2016 for an effort in this regard).

\footnotetext{
${ }^{4}$ Global financial integration could also worsen the trade-offs authorities face when pursuing financial stability objectives along with more standard macroeconomic stabilization goals (Obstfeld 2015). This is because greater openness to international financial markets would likely diminish the effectiveness of macroprudential tools, which would suffer more from leakage problems (IMF-FSB-BIS 2016).

${ }^{5}$ According to the "financial trilemma" put forward by Shoenmaker (2013), only two of the following three goals can be achieved simultaneously: (1) national autonomy over financial policies; (2) international financial integration; and (3) financial stability.

${ }^{6}$ See also Kennedy and Palerm (2014); and Bekaert and others (2016), among many others.
} 
This paper seeks to address this issue by focusing on measures of financial conditions that are purged of macroeconomic fundamentals, acknowledging the difficulties and limitations inherent to such an endeavor.

\section{Constructing Financial Conditions Indices Across Advanced and Emerging Market Economies}

Most of the literature has focused on developing FCIs for a few advanced economies. Many FCIs for the U.S have been developed, including by academics, Federal Reserve Banks, investment banks, and other institutions. ${ }^{7}$ Relatively long time series facilitate the tracking of U.S. financial markets, which include more developed segments covering corporate bonds, commercial paper, asset-backed securities, and mortgage markets. FCIs are also available for a few selected advanced economies, typically those in the Group of Seven, and sometimes for the euro area as well. ${ }^{8}$ In contrast, FCIs for emerging market economies are rare. ${ }^{9}$ Despite the dramatic transformation in their financial markets in recent decades, greater variety across emerging market economies and relatively short times series for monitoring their financial segments have made it difficult to develop FCIs for these economies. Moreover, there is not a set of comprehensive and consistently estimated FCIs that facilitate crosscountry analysis for both major advanced and emerging market economies. ${ }^{10}$

We first develop FCIs for major advanced and emerging market economies. For the purposes of this paper, latent FCIs are extracted from an array of financial variables while taking account of growth and inflation. The FCIs are estimated based on the time-varying factor augmented vector autoregressive model (TVP-FAVAR) developed by Koop and Korobilis (2014) which builds on the estimation of Primiceri's (2005) time-varying parameter vector autoregression (TVP-VAR) model and the dynamic factor models of Doz, Giannone, and Reichlin (2011). The model takes the following form:

$$
\begin{gathered}
x_{t}=\lambda_{t}^{Y} Y_{t}+\lambda_{t}^{f} f_{t}+u_{t} \\
{\left[\begin{array}{l}
Y_{t} \\
f_{t}
\end{array}\right]=B_{1, t}\left[\begin{array}{l}
Y_{t-1} \\
f_{t-1}
\end{array}\right]+B_{2, t}\left[\begin{array}{l}
Y_{t-2} \\
f_{t-2}
\end{array}\right]+\cdots+\varepsilon_{t}}
\end{gathered}
$$

in which $x$ is a vector of financial variables, $Y$ is a vector of macroeconomic variables of interest (including growth in industrial production and inflation), $\lambda_{t}^{y}$ are coefficient estimates, and $\lambda_{t}^{f}$ are the factor loading, while $f$ is the latent factor, interpreted as the FCI.

\footnotetext{
${ }^{7}$ See Hatzius and others (2010); Matheson (2012); Koop and Korobilis (2014); Brave and Butters (2011); Hakkio and Keeton (2009); Carlson, Lewis, and Nelson (2012); Kliesen, Owyang, and Vermann (2012); Oet and others (2011).

${ }^{8}$ See Illing and Liu (2003); Davis, Kirby, and Warren (2016); Moccero, Darracq Paries, and Maurin (2014); Guichard, Haugh, and Turner (2009); Hollo, Kremer, and Lo Duca (2012); Dattels and others (2010); Schüler, Hiebert, and Peltonen (2016).

${ }^{9}$ Exceptions include Brandão-Marques and Perez-Ruiz forthcoming; Gumata, Klein, and Ndou (2012); and Kara, Ozlu, and Unalmis (2012) for Chile, South Africa, and Turkey, respectively.

${ }^{10}$ Cardarelli, Elekdag, and Lall (2011) develop FSIs for 17 advanced economies and Balakrishnan and others (2009) for major emerging market economies. Osorio, Unsal, and Pongsaparn (2011) develop FCIs for 13 selected Asian economies.
}

(continued...) 
The TVP-FAVAR jointly considers the dynamic interactions of the financial variables used to construct the FCI and macroeconomic fundamentals, and has two notable advantages. First, the method aims to purge the FCI of the effects of macroeconomic conditions. ${ }^{11}$ Although empirically difficult, conceptually this purging is desirable - ideally, the estimated FCIs would therefore entail primarily exogenous shifts in financial conditions that are distinct from the endogenous reflection of macroeconomic fundamentals. Second, because the parameters can change, the model can account for the evolving relationships between macroeconomic and financial variables over time. Another advantage of the TVP-FAVAR model is that the time-varying parameters help account for changes in (policy) regimes and, for example, financial-accelerator-related dynamics. Similarly, the TVP-FAVAR recognizes that financial shocks in various periods can be transmitted to the real economy with varying intensity.

In principle, the range of possible financial variables to include in an FCI is vast. In practice, however, most studies use a limited array of financial variables. For example, the Organization for Economic Co-Operation and Development develops FCIs for six major advanced economies using seven variables. Even for the U.S., the Kansas City Financial Stress Index is based on 11 variables. Although Hatzius and others (2010) use up to 45 variables, and the Federal Reserve Bank of Chicago uses more than 100 in its U.S. factor models, Boivin and $\mathrm{Ng}$ (2006) emphasize that including more data does not always yield better results.

Our choice of variables is guided by two considerations, one conceptual and the other practical. Conceptually, since the paper focuses on how global factors affect financial conditions in domestic markets, variables measuring the ease of access to finance on international markets are not included. ${ }^{12}$ Regarding practical considerations, the choice of variables should be consistent across countries and reflect as many segments of the financial system as possible. Accordingly, the FCI should include the equity, housing, bond, and interbank markets to capture the various channels through which monetary and macroprudential policies can influence the broader economy. Following the literature, the financial variables used include various interest rates and spreads (for example, changes in

\footnotetext{
${ }^{11}$ Initially, the FCIs are purged only of the effect of current macroeconomic conditions. However, financial variables can also reflect expectations of future macroeconomic developments. The FCIs are not purged of these expectations about the future in the baseline estimations to the extent that these expectations cannot be captured by the past and current behavior of macroeconomic variables. This is an issue common to all FCIs. As a robustness check, professional forecasts of macroeconomic variables were considered as controls in the case of the United States (based on data availability), which did not result in any material changes to the FCI (consistent with Koop and Korobilis 2014).

${ }^{12}$ For financially open economies, financial conditions encompass the ease of access to funding in both the domestic jurisdiction and across borders. When firms rely more on international markets for funding, global factors are expected to have a larger direct impact on their financing conditions. For the purposes of this paper, the more indirect channel is considered, whereby global factors are potentially a driver of domestic financial conditions. Similarly, the exchange rate is not included in the FCI. As mentioned earlier, exchange-rate movements may influence domestic financial conditions, for example, by altering the net worth of borrowers and thereby their terms of access to finance. The analysis aims at measuring these indirect effects. Including the exchange rate directly in the FCI would overstate the influence of global conditions on domestic financial conditions, for example, in economies where exchange rate movements have little effect on domestic financial conditions or where they effectively serve as an insulating buffer.
} 
longer-term interest rates, and corporate, interbank, and term spreads), asset price returns (equity and house price returns), equity return volatility, and credit growth. Where available, survey-based information (lending standards) can provide additional information about financial frictions. Naturally, as the structure of and products in financial systems evolve, the variables most relevant for tracking financial conditions may change.

The financial conditions indices (FCIs) are estimated for 1990-2016 at monthly frequency for 43 advanced and emerging market economies (see Appendix Table 1). The FCIs are based on 10 underlying financial indicators consistent with the literature based on data availability (corporate spreads, term spreads, interbank spreads, sovereign spreads, changes in long-term interest rates, equity and house price returns, equity return volatility, changes in the market share of the financial sector, and credit growth (see Appendix Table 2). ${ }^{13}$

\section{Financial Conditions AROUND THE WORLD}

\section{A. Financial Conditions Indices: Selected Countries}

Given its central role in the global financial system, the United States is a natural starting point for appraising the usefulness of the FCIs developed here. In addition, because many FCIs have been developed for the United States, several benchmarks can facilitate comparisons across complementary approaches. It is reassuring that the pattern of the U.S. FCI developed in this paper closely tracks counterparts developed by the IMF and other institutions, such as the Federal Reserve Banks of Chicago and Kansas City during 1990-2016 (Figure 1). ${ }^{14}$ Note that positive (negative) values of the FCI indicate that financial conditions are tighter (looser) than on average, which corresponds to, for example, higher(lower-) than-average corporate spreads and lower- (higher-) than-average credit growth.

At the same time, the fluctuations in the FCI appear to capture key U.S. financial events quite well. After a period of relative tranquility in the early 1990s, financial conditions tightened as stock markets, in particular, were rattled by the collapse of Long-Term Capital Management, a hedge fund, in 1998. The FCI remained elevated because of the dot-com crash in 2000, when stock market declines were led by the technology sector. Then around 2002, the demise of accounting firm Arthur Andersen and the bankruptcy of telecommunications corporation WorldCom (the largest in U.S. history at the time), among other events, resulted in tighter financial conditions. After a period of favorable conditions, the global financial crisis broke

\footnotetext{
${ }^{13}$ Various additional financial variables were also used as robustness checks. For instance, lending standards were included in the case of the U.S. based on data availability, resulting in a broadly similar FCI. Sovereign spreads were included to account for the fact that the short-term sovereign yield may not be a good proxy for the risk-free rate during crises. For example, during the euro area crisis, short-term sovereign yields shot up more than corporate yields (which may reflect illiquidity in the corporate bond market) resulting in a counterintuitive decrease in the corporate spread. Likewise, the sovereign spread is often a good proxy for financing conditions for domestic firms - particularly in emerging market economies, where data on corporate spreads are scarcer (the FCIs are generally robust to their exclusion, however).

14 The IMF financial stress indices (FSIs) seek primarily to identify episodes of acute financial stress - that is, when financial intermediation is impaired (extreme events are typically considered outright crises). In practice, FSIs and FCIs can display broadly similar patterns. Here, the IMF FSIs are entirely price based, partly explaining why they tend to be more volatile. See Cardarelli, Elekdag, and Lall (2011) for further details.
} 
out in 2008, resulting in an unprecedented spike in the FCI. More recently, the FCI has been on a gradual uptrend, although still indicating broadly accommodative conditions.

The FCIs for selected small open economies seem to reflect their financial histories well. For instance, in Russia, the FCI tightened dramatically during 1998 as a consequence of the acute financial distress experienced by the country at the time, with the degree of tightening outpacing that encountered 10 years later during the global financial crisis (Figure 2). By contrast, financial conditions in Korea were tighter during the global financial crisis than they were during the Asian financial crisis (1997-98). Likewise, for Chile, the global financial crisis represents the sharpest spike in the FCI over the past two decades. Last, for a small open euro area economy, the Netherlands, financial conditions tightened to almost the same extent during the euro area crisis and the global financial crisis. ${ }^{15}$

Figure 1. United States: Financial Conditions Indices, 1991-2016 (Standard deviations)
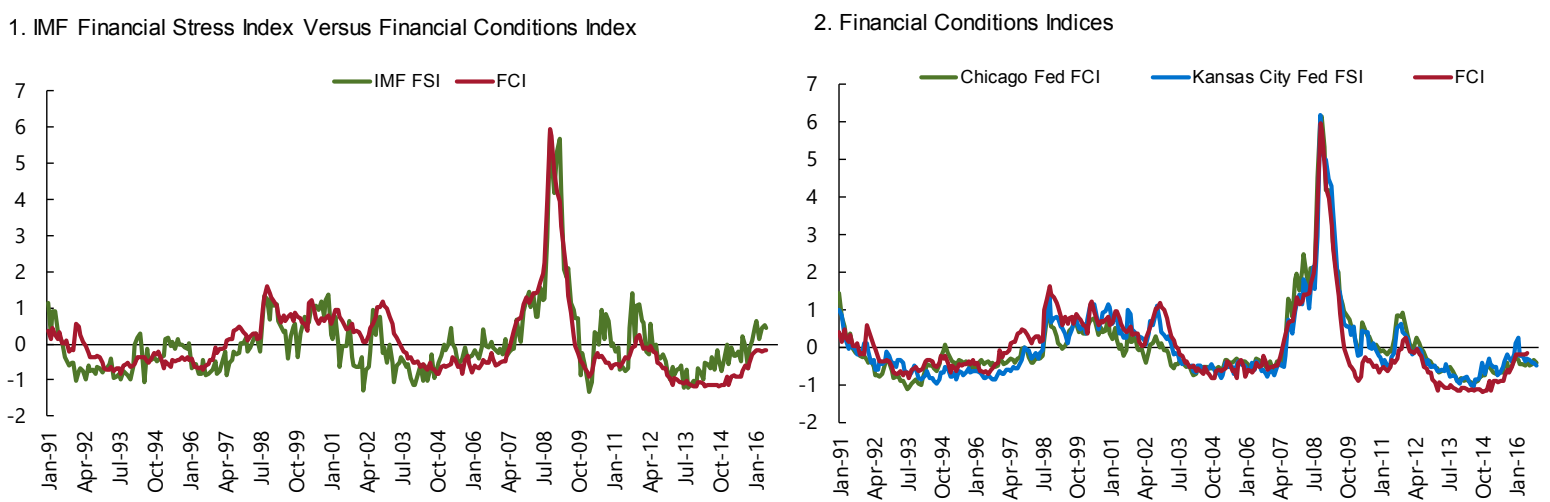

Sources: Federal Reserve Bank of Chicago; Federal Reserve Bank of Kansas City; IMF, Global Data Source database; and authors' estimates.

Note: Higher values indicate tighter-than-average financial conditions. The IMF FSI aims to identify episodes of acute financial stress, when financial intermediation is impaired, similar to the Kansas City Fed FSI. The Chicago Fed FCl summarizes U.S. financial conditions in money markets and debt and equity markets and in the traditional and shadow banking systems. $\mathrm{FCl}=$ financial conditions index; Fed = Federal Reserve Bank; FSI = financial stress index .

\footnotetext{
${ }^{15}$ Examination of the factor loadings across countries' FCIs reveals that interbank and corporate spreads, equity return volatility, and changes in house prices are at the top of the list of the underlying financial variables contributing to countries' FCIs. This result is broadly consistent for advanced and emerging market economies and in line with those in Hatzius and others (2010).
} 
Figure 2. Selected Advanced and Emerging Market Economies:

Financial Conditions Indices

(Standard deviations)
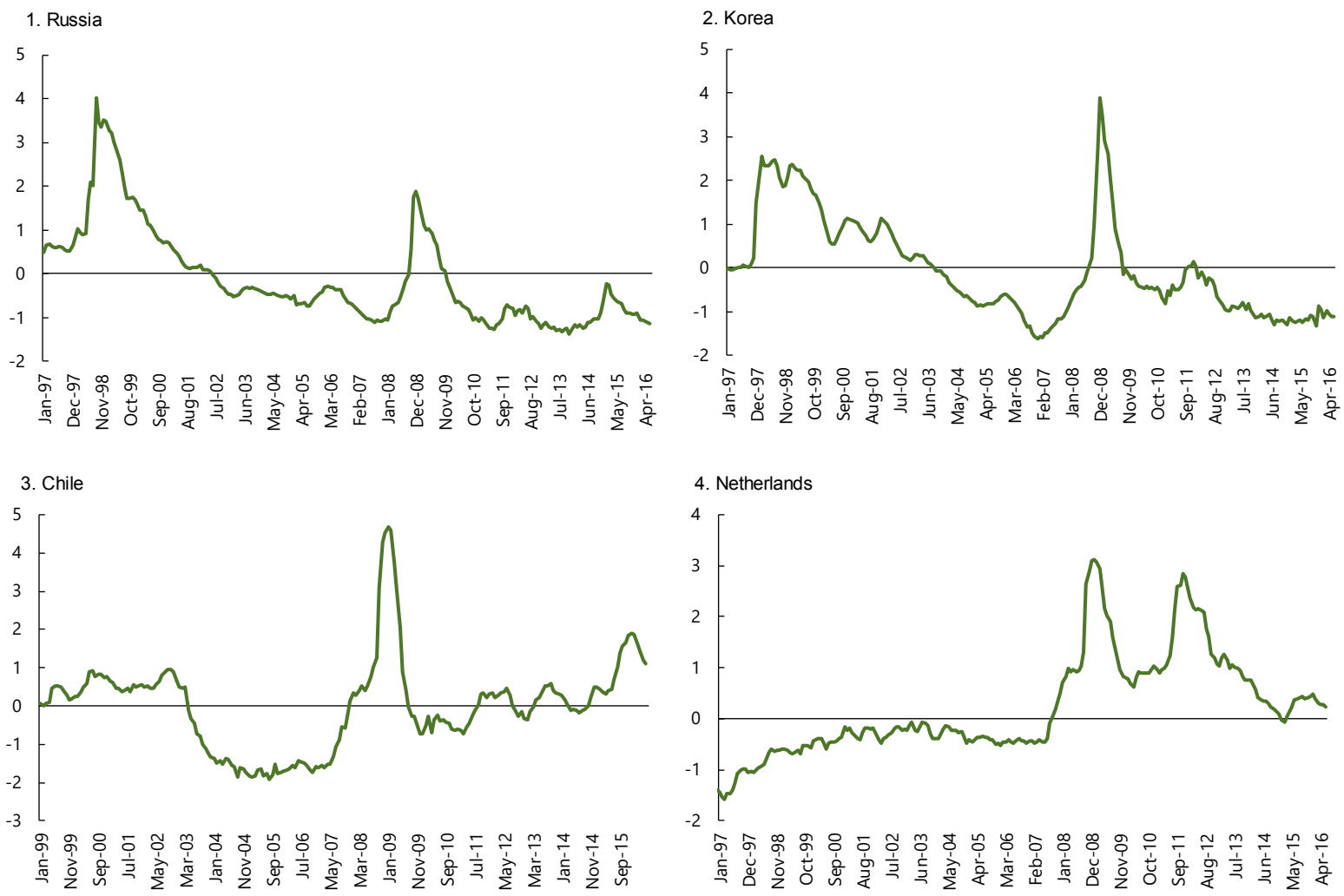

Source: Authors' estimates.

Note: Higher values indicate tighter-than-average financial conditions.

\section{B. The Evolution of Financial Conditions Around the World}

To uncover key patterns across countries' financial conditions, this subsection employs a statistical dynamic factor model (DFM) to generate multiple unobservable (latent) factors. Specifically, the time series factor analysis methodology described in Gilbert and Meijer (2005), which does not require independent and identically distributed observations, is used. The three-factor version of the model can be represented as follows:

$$
F C I_{c, t}=\lambda_{1, c} x_{1, t}+\lambda_{2, c} x_{2, t}+\lambda_{3, c} x_{3, t}
$$

in which $x_{1, t}$, and $\lambda_{1, c}$, for example, represent the first common time-varying factor and the country-specific loading associated with it ( $c$ and $t$ denote country and time, respectively).

Although the factors generated from DFMs can be subject to various interpretations, an interesting story emerges in the case of the $43 \mathrm{FCIs}$ investigated in this paper. It appears that the financial conditions around the world can be summarized by three factors, which can be characterized by the three main historical crisis episodes over the past two decades.

In particular, there seems to be an "emerging market" factor, a "euro area" factor, and a 
"global financial crisis" factor (Figure 3). Although each factor spikes during the global financial crisis, the emerging market and euro area factors also depict markedly tighter financial conditions during the late 1990s and around 2012, respectively.

Figure 3. Three-Factor Model Based on Financial Conditions Index, 1995-2016 (Standard deviations)

_Global financial crisis factor _Emerging market factor —Euro area factor

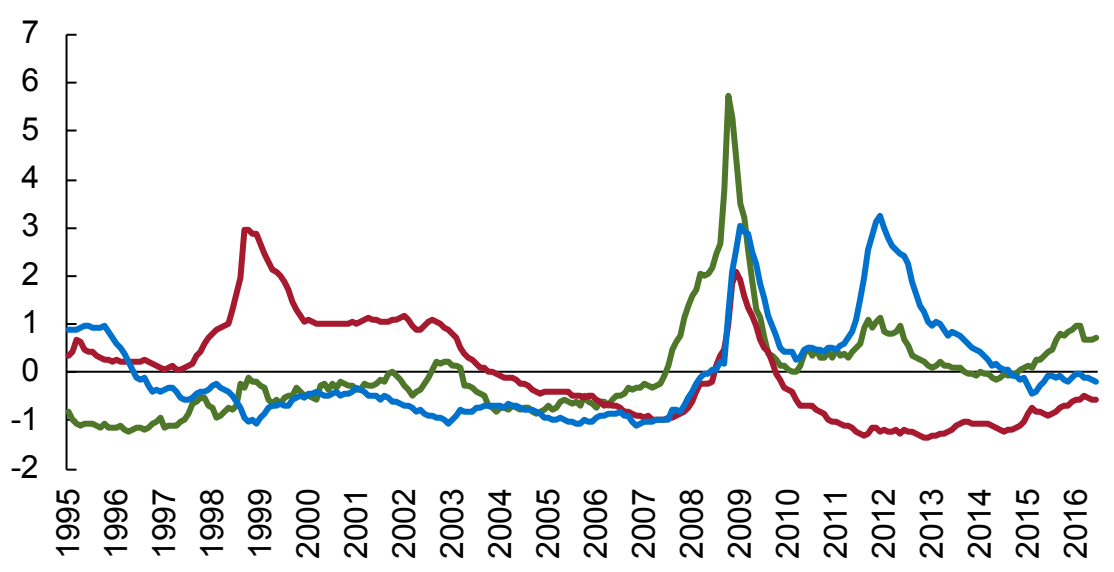

Source: Authors' Estimates.

Note: Higher values indicate tighter-than-average financial conditions. Based on a dynamic factor model, the figure displays three latent factors that summarize the main patterns across countries' financial conditions indices.

Nevertheless, a single global factor adequately summarizes financial conditions across countries. Such a factor is consistent with the notion of a global financial cycle discussed in Miranda-Agrippino and Rey (2015). To assess robustness, a single global factor was also computed using principal components analysis (PCA). As shown in Figure 4, these two factors move in tandem. Furthermore, these single factors (global financial factors or global financial conditions) closely track the movements in the U.S. FCI and the VIX (Figure 4). In fact, the average correlation between the U.S. FCI and the two measures of global financial conditions and the VIX is 82 percent. These findings are in line with Rey's (2013) argument that global financial conditions are strongly driven by the United States, the key country in the international monetary system. Part of the reason for this predominance is due to the particular role of the U.S. dollar as an international currency with important roles in invoicing, issuance of financial assets, and commodity trading, among others (see also IMF 2014a). 
Figure 4. Single Factor Versus Principal Component Analysis, 1995-2015

(Standard deviations)

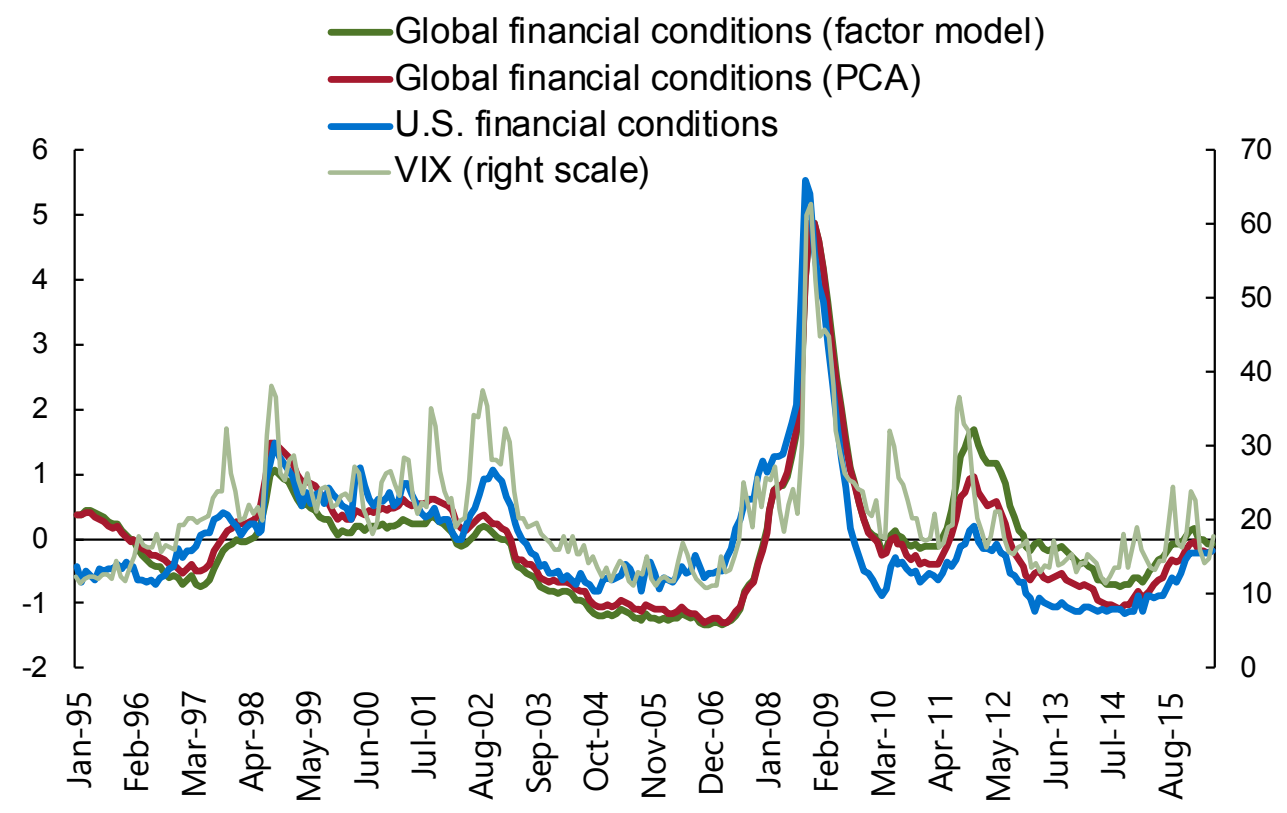

Source: Haver Analytics and authors' estimates.

Note: The figure displays two measures of global financial conditions derived from a factor model (global financial cycle) or from principal component analysis, the U.S. financial conditions index (FCl), and the Chicago board options exchange volatility index (VIX). Higher values indicate tighter-than-average financial conditions.

A sizable share of fluctuations in countries' financial conditions can be explained by global financial shocks. This can be inferred from the $\mathrm{R}^{2}$ from a panel regression model in which countries' FCIs are regressed on the measures of the global financial cycle. On average, global financial conditions account for about 30 percent of the variation in financial conditions across countries, and though not shown, the proportion reaches almost 70 percent in several economies (Figure 5). As would be expected, the proportion of FCI variability explained by the three-factor model is larger than its single-factor counterpart and is greater than 40 percent. These magnitudes are larger than those in Miranda-Agrippino and Rey (2015), for example, who report that a measure of global financial conditions accounts for about 21 percent of the variation across risky asset prices. 
Figure 5. Variance Accounted for by One and Three Factor Models (In percent)

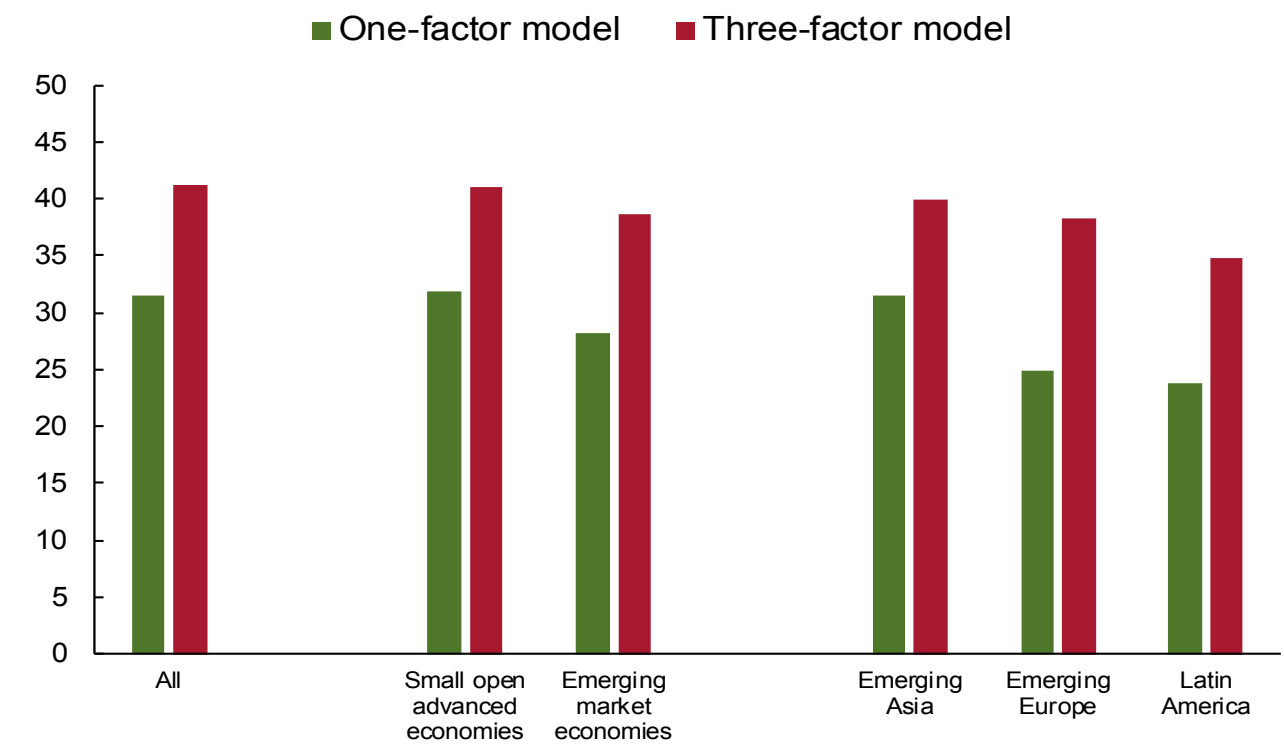

Source: Authors' estimates.

Note: The figure displays the share of countries' $\mathrm{FCl}$ attributable to global factors based on a one or three-factor model-specifically, the $R^{2}$ from panel regression models in which countries' FCls are regressed on measures of global financial conditions based on the one- or three-factor model. Simple averages are used.

However, no clear evidence indicates that the importance of global financial conditions has been markedly increasing over the past two decades. Using either a 36- or 60-month rolling window, we compute the total variance explained by the first principal component across countries' FCIs. The share of variation across FCIs accounted for by global financial conditions displays some cyclical patterns, especially during the global financial crisis, but portrays a broadly flat trajectory when viewed over the past 20 years (Figure 6). These patterns are robust to Forbes and Rigobon (2002)-type adjustments, which correct for the fact that correlations increase mechanically when volatility is higher. As an example of an additional robustness exercise, the average $R^{2}$ statistics based on 36- and 60-month rolling regressions of countries' FCIs on global factors reveal broadly similar patterns. For instance, to shed light on what might be driving these patterns, similar exercises were conducted by region (Figures 7 and 8), which appear to broadly corroborate the lack of a sharp uptrend in the variance across countries' FCIs explained by measures of global financial conditions. Although FCIs encompass various asset classes, these patterns are consistent with Bekaert and others (2016), who document that equity return correlations display an upward trend from the end of the 1990s through the global financial crisis, but then decline notably. ${ }^{16}$

${ }^{16}$ Carrieri, Chaieb, and Errunza (2013) argue that emerging markets are not yet effectively integrated with global markets. 
Figure 6. Variance Attributable to Global Conditions, 1995-2016 (In percent)

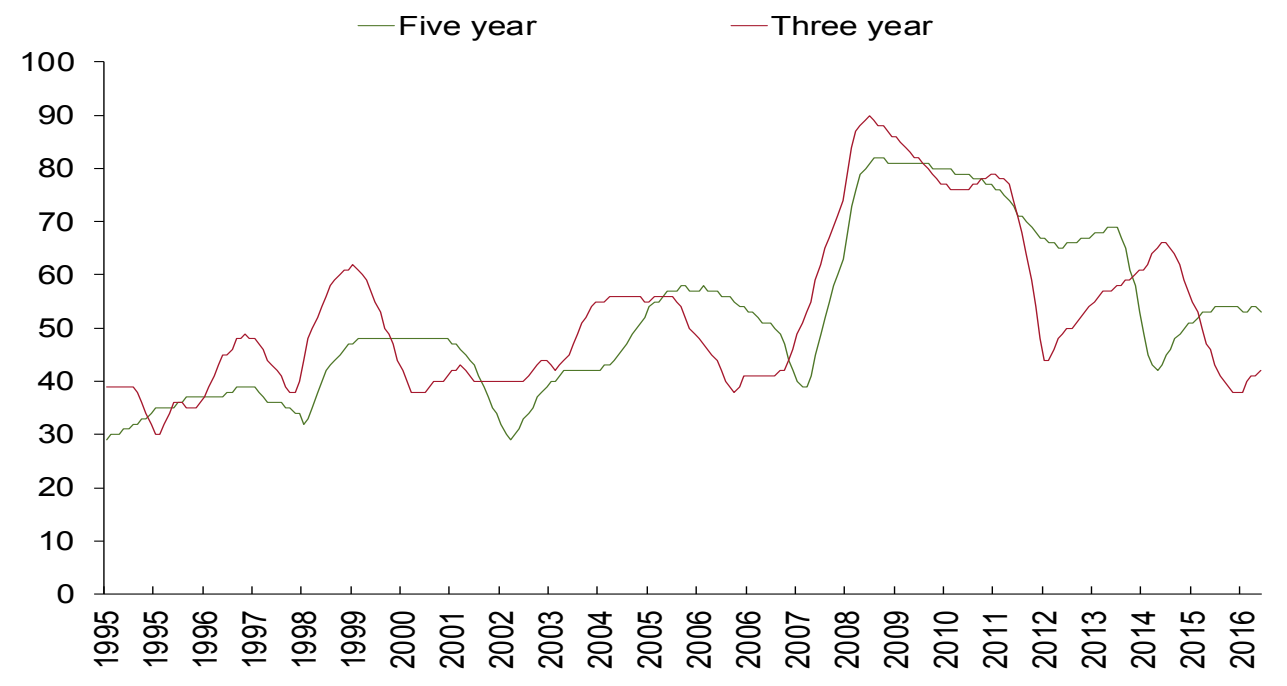

Source: Authors' estimates.

Note: The figure displays how the share of countries' $\mathrm{FCl}$ variability attributable to global financial conditions changes over time. Specifically, it presents the total variance explained by the first principal component across countries' $\mathrm{FCl}$ using either a 36- or 60-month rolling window.

Figure 7. Robustness: Variance Attributable to Global Financial Conditions, 19952016

(In percent)

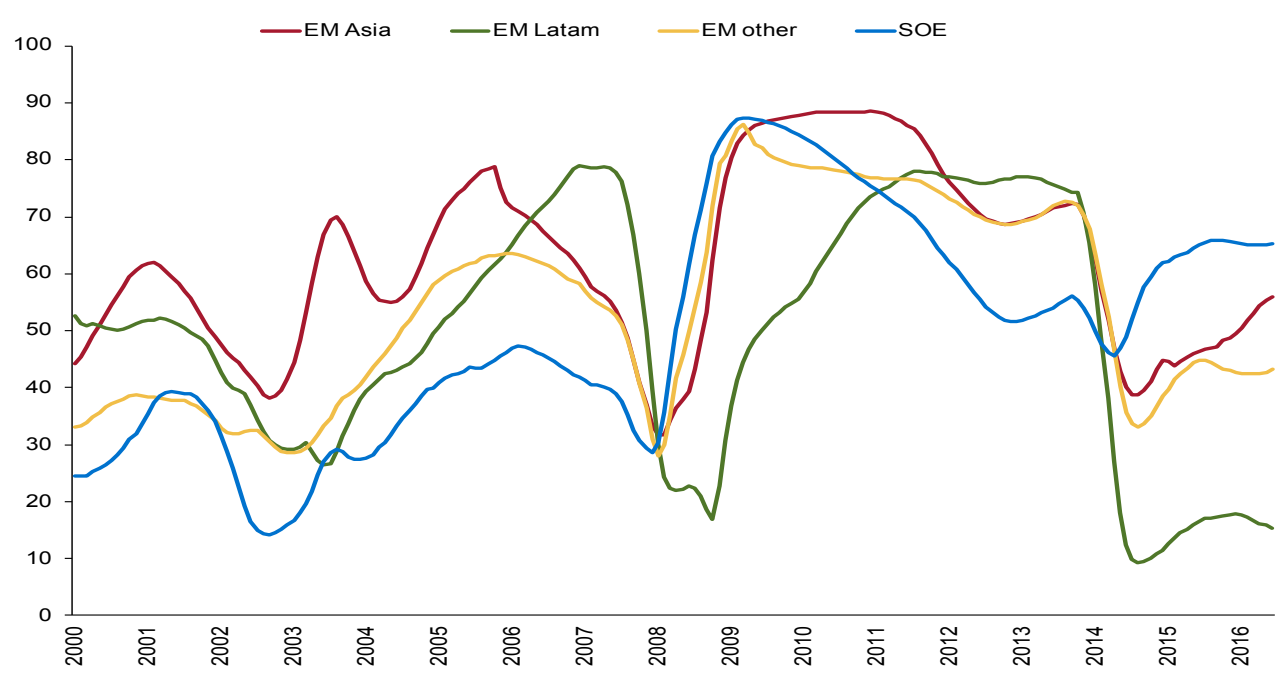

Source: Authors' estimates.

Note: This chart presents the R-squared of a rolling regression, over a three-year window of countries' domestic $\mathrm{FCl}$ on global $\mathrm{FCl}$, where global $\mathrm{FCl}$ is constructed from a one-factor dynamic model. SOE denotes 39-small advanced and emerging market economies in the sample (excludes Germany, Japan, U.S., U.K.). 
Figure 8. Robustness: Variance Attributable to Global Financial Conditions, 1995-2016, In a Three-Factor Model by Regions

(In Percent)

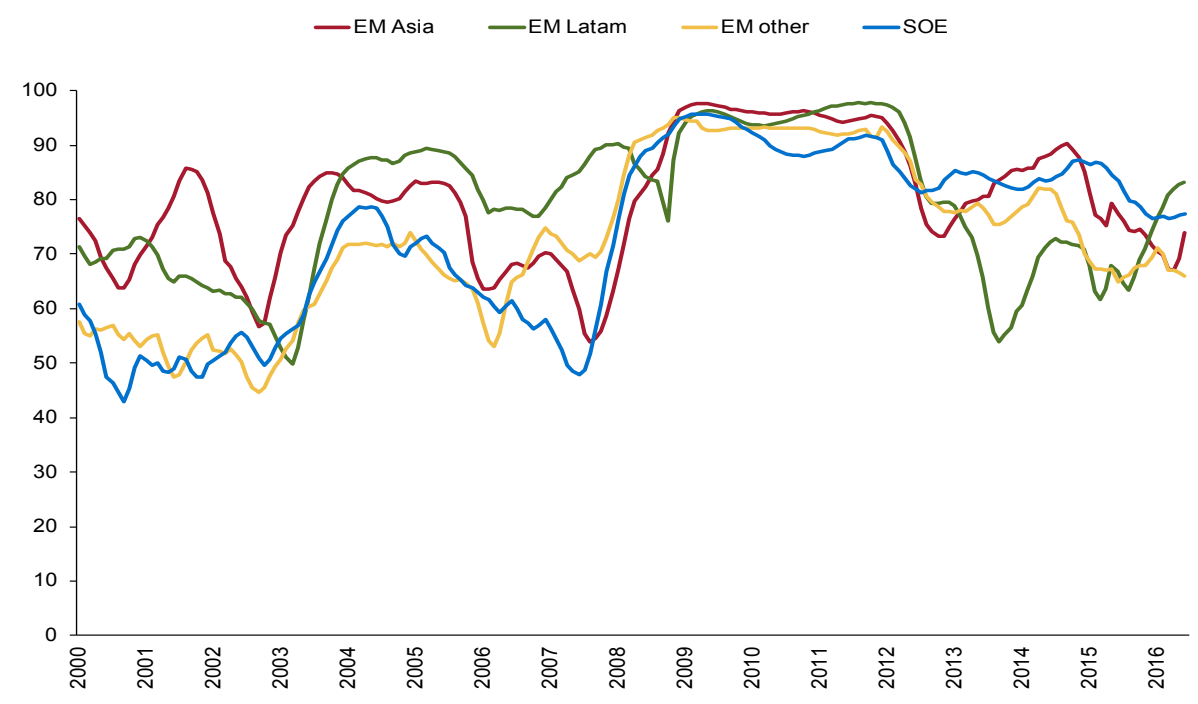

Source: Authors' estimates.

Note: This chart presents the R-squared of a rolling regression, over a three-year window, of countries' domestic $\mathrm{FCl}$ on global $\mathrm{FCl}$, where global $\mathrm{FCl}$ is constructed from a three-factor dynamic model. SOE denotes the 39-small advanced and emerging market economies in the sample (excludes Germany, Japan, U.S., U.K.).

\section{Country Characteristics and Sensitivity to Global Financial Conditions}

Country characteristics are likely to influence how sensitive domestic financial conditions are to global financial shocks. Based on the findings discussed earlier, the U.S. FCI is taken as a proxy for global financial conditions. ${ }^{17}$ Key country characteristics considered include financial linkages with the United States (foreign direct investment, banking, portfolio), financial openness and development, institutional quality, and the exchange rate regime (see Forbes and Chinn 2004; Aizenman, Chinn, and Ito 2015; and Sahay and others 2015). Appendix Table 2 lists the set of variables used and their sources.

The expectation is that FCIs of countries that are more financially open and that feature stronger financial linkages with the United States, for example, should be more sensitive to global financial conditions. Conversely, countries with strong institutional and policy frameworks and deep financial markets should display less sensitivity (Chinn and Ito 2007; Alfaro, Kalemli-Ozcan, and Volosovych 2008; Brandão-Marques, Gelos, and Melgar

\footnotetext{
${ }^{17}$ Analysis based on Granger causality and convergent cross-mapping confirm the importance of U.S. FCIs relative to other FCIs across countries. The U.S. FCIs provide more statistically significant information about future FCIs in other countries than do other financial centers (including Germany, Japan, and the United Kingdom), with an average $p$-value of 7 percent. Analysis using convergent cross-mapping (which complements Granger causality using nonlinear methods as described in Sugihara and others 2012) suggests that U.S. FCIs reduce prediction errors to the greatest extent across countries. Although the U.S. FCI is taken as a proxy for global financial conditions, U.S. financial conditions may also be affected by financial developments in other advanced and emerging market economies.
} 
2013). ${ }^{18}$ Given that an attempt has been made to purge the FCIs of macroeconomic drivers, real economic linkages (such as trade ties) should not be among the determinants that help explain the influence of U.S. financial conditions on local FCIs. Exchange rate regimes may not matter very much for the transmission of financial conditions across countries because financial conditions work through the various channels that typically cannot be fully counterbalanced by exchange rate movements alone (Obstfeld 2015).

In what follows, we investigate the extent to which FCIs across countries are correlated with the U.S. FCI, using a panel of small open advanced and emerging market economies. We explore how the various country characteristics discussed earlier strengthen or weaken this correlation. In particular, a panel regression model is estimated based on other studies in the literature that analyze the relationship between domestic financial variables (for instance, stock returns and sovereign bond yields) and typically the VIX (see, for instance, Bowman, Londono, and Sapriza 2015 as well as Passari and Rey 2015). The sample covers 39 advanced and emerging market economies from 1991 to 2016. Countries that could be main drivers of global financial conditions (Germany, Japan, the United Kingdom, the United States) are excluded. The baseline specification can be summarized as follows:

$$
F C I_{c, t}=\alpha_{i}+\beta_{1} F C I_{t}^{U S}+\beta_{2} C C H A R_{c, t-1}+\beta_{3} F C I_{t}^{U S} * C C H A R_{c, t-1}+\beta_{4} Z_{c, t-1}+\varepsilon_{i t}
$$

in which FCI denotes domestic financial conditions, and country characteristics (CCHAR) include measures of integration (trade and financial openness), linkages to the United States (FDI, banking, portfolio, trade), exchange rate flexibility, financial development, and rule of law (for country $c$ in year $t$ ). Additional controls $(Z)$ include global variables (commodity price inflation and global growth) and domestic variables (growth, inflation, and current account balance). All explanatory variables except the global driver are lagged to mitigate endogeneity concerns. The model includes country fixed effects, and standard errors are clustered at the country level.

Financial linkages are most closely associated with the extent to which FCIs are influenced by global financial conditions. In particular, FCIs in countries with stronger financial linkages (proxied by the stock of foreign direct investment) with the United States tend to be more synchronized with global financial conditions (see Table 1 for a summary and Table 2 for the baseline results). Portfolio linkages also matter (and bank linkages to a lesser extent), but results of their importance are not as robust across various specifications (signs were also mixed across specifications). Possibly, because foreign direct investment tends to be more permanent, it captures financial linkages better than portfolio and bank linkages. Greater financial development in general, and deeper financial (equity, bond) market depth in particular, are associated with an attenuated impact of global financial shocks on domestic FCIs. Furthermore, along with the overall financial markets indices developed by Sahay and others (2015), the financial markets depth subindex tends to be statistically significant and

\footnotetext{
${ }^{18}$ It is sometimes argued that more liquid markets are more exposed to sell-offs by foreign investors. However, as discussed in Sahay and others (2015), although some emerging market economies with relatively deeper and more liquid financial markets were strongly affected during the taper tantrum in 2013, their more-developed financial markets subsequently facilitated the needed adjustment.
} 
robust across specifications (Table 3 ). This subindex includes measures of equity and bond market size and liquidity.

\section{Table 1. Summary: Determinants of the Sensitivity of Domestic FCls to Global Financial Shocks}

\begin{tabular}{lccc}
\hline Variable & Expected Sign & Estimated Sign & Significance \\
\hline Direct Effect of U.S. FCI & + & & $* *$ \\
Interactions with: & & + & $*$ \\
FDI Linkages with the U.S. & + & - & $*$ \\
Portfolio Linkages with the U.S. & + & + & \\
Banking Linkages with the U.S. & + & + & $*$ \\
Trade Linkages with the U.S. & + & + & \\
Trade Openness & + & + & $*$ \\
Financial Openness & + & - & \\
Exchange Rate Flexibility & - & - \\
Financial Development & - & & \\
Rule of Law & - & & \\
\hline
\end{tabular}

Source: Authors' estimates.

Note: This table summarizes panel regressions in which countries' domestic FCls are regressed against a measure of global financial conditions (U.S. FCl), various country characteristics, and their interactions. Regressions include country fixed-effects terms, and standard errors are clustered at the country level. See text for details on baseline specifications. $\mathrm{FCl}=$ financial conditions index; FDI = foreign direct investments; ${ }^{* \star \star} \mathrm{p}<0.01,{ }^{* \star} \mathrm{p}<0.05,{ }^{*} \mathrm{p}<0.1$.

These findings echo the conclusions in IMF (2014b) which finds that a larger domestic investor base and deeper banking systems and capital markets can increase the resilience of emerging market economies to external financial shocks. Trade linkages to the United States do not seem to matter, although trade relationships with the rest of the world appear to play a role - possibly, this variable captures other factors such as indirect financial linkages. Results are generally robust to alternative specifications, such as the inclusion of lags of the global driver and alternative measures of domestic macroeconomic conditions including growth expectations based on Consensus Economics forecasts. ${ }^{19}$

No clear pattern emerges regarding the exchange rate regime and capital account opennessresults that are broadly consistent with Aizenman, Chinn, and Ito (2015). On the former, recall that in contrast to a general measure of capital account openness, a more specific

\footnotetext{
${ }^{19}$ FCIs are by construction standardized at the country level (to aggregate information from the multiple financial variables). This implies that a one standard deviation change in the FCI can correspond to different changes in, for example, corporate spreads in different countries, which could bias the results. At the same time, robustness analysis based on individual financial markets (including corporate spreads and equity returns) confirms the dampening role of financial development.
} 
measure of financial integration as captured by foreign direct investment linkages with the United States is statistically significant. On the latter, the finding is generally in line with evidence that exchange rate flexibility allows for considerable independence at the short end of the term structure, but less so when it comes to broader measures of financial conditions, including, for example, longer-term rates (Obstfeld 2015). ${ }^{20}$

\footnotetext{
${ }^{20}$ Regarding the role of exchange rate regimes, recall that financial conditions can be transmitted across countries through various channels that typically cannot be fully offset by exchange rate movements. Furthermore, relative to the sample in this paper, which considers 43 advanced and emerging market economies, studies that find that exchange rate flexibility does confer monetary autonomy use larger sets of countries (for instance, Obstfeld (2015) considers 70 countries) that are much more heterogeneous in composition (and include low-income countries and other countries with a variety of exchange rate regimes, which helps uncover the potential role exchange rate flexibility can play).
} 
Table 2. Determinants of Sensitivity to Global Financial Conditions

\begin{tabular}{|c|c|c|c|c|c|c|c|c|}
\hline & (1) & $(2)$ & (3) & (4) & (5) & (6) & (7) & (8) \\
\hline U.S. FCI $(\operatorname{lag}=0)$ & $\begin{array}{c}0.3310^{* \star *} \\
(0.000)\end{array}$ & $\begin{array}{c}0.2787^{\text {*** }} \\
(0.000)\end{array}$ & $\begin{array}{c}0.3328^{*-*} \\
(0.000)\end{array}$ & $\begin{array}{c}0.3278^{\text {* }} \\
(0.000)\end{array}$ & $\begin{array}{c}0.4728^{* \star *} \\
(0.000)\end{array}$ & $\begin{array}{c}0.4403^{\star \star \star k} \\
(0.000)\end{array}$ & $\begin{array}{c}0.4641^{\star \star \star \star *} \\
(0.000)\end{array}$ & $\begin{array}{c}0.4645^{\star \star-k} \\
(0.000)\end{array}$ \\
\hline Real Growth $(\operatorname{lag}=1)$ & $\begin{array}{c}-0.0922^{\text {**** }} \\
(0.000)\end{array}$ & $\begin{array}{c}-0.0964^{* * *} \\
(0.000)\end{array}$ & $\begin{array}{c}-0.0939^{*-k} \\
(0.000)\end{array}$ & $\begin{array}{c}-0.0931^{\text {t*k }} \\
(0.000)\end{array}$ & $\begin{array}{c}-0.0918^{\text {***}} \\
(0.000)\end{array}$ & $\begin{array}{c}-0.0959^{* \kappa \hbar} \\
(0.000)\end{array}$ & $\begin{array}{c}-0.0936^{\text {t-kt}} \\
(0.000)\end{array}$ & $\begin{array}{c}-0.0928^{*-* *} \\
(0.000)\end{array}$ \\
\hline Inflation (lag=1) & $\begin{array}{l}0.0001 \\
(0.779)\end{array}$ & $\begin{array}{c}-0.0001 \\
(0.797)\end{array}$ & $\begin{array}{c}-0.0001 \\
(0.855)\end{array}$ & $\begin{array}{r}-0.0004 \\
(0.304)\end{array}$ & $\begin{array}{l}0.0001 \\
(0.794)\end{array}$ & $\begin{array}{c}-0.0001 \\
(0.777)\end{array}$ & $\begin{array}{r}-0.0001 \\
(0.845)\end{array}$ & $\begin{array}{r}-0.0004 \\
(0.295)\end{array}$ \\
\hline Current Account Balance to GDP (lag=1) & $\begin{array}{c}-0.0039 \\
(0.753)\end{array}$ & $\begin{array}{l}-0.0023 \\
(0.842)\end{array}$ & $\begin{array}{c}-0.0084 \\
(0.491)\end{array}$ & $\begin{array}{c}-0.0075 \\
(0.552)\end{array}$ & $\begin{array}{c}-0.0038 \\
(0.760)\end{array}$ & $\begin{array}{c}-0.0021 \\
(0.853)\end{array}$ & $\begin{array}{c}-0.0082 \\
(0.498)\end{array}$ & $\begin{array}{c}-0.0074 \\
(0.557)\end{array}$ \\
\hline U.S. FCI $(\operatorname{lag}=1)$ & $\begin{array}{l}0.0563 \\
(0.188)\end{array}$ & $\begin{array}{c}0.0757^{*} \\
(0.075)\end{array}$ & $\begin{array}{l}0.0557 \\
(0.195)\end{array}$ & $\begin{array}{l}0.0540 \\
(0.210)\end{array}$ & & & & \\
\hline U.S. FCI $(\operatorname{lag}=2)$ & $\begin{array}{c}0.2343^{* * k} \\
(0.000)\end{array}$ & $\begin{array}{c}0.2074^{\text {k** }} \\
(0.000)\end{array}$ & $\begin{array}{c}0.2445^{\star-k-k} \\
(0.000)\end{array}$ & $\begin{array}{c}0.2393^{\text {*nt }} \\
(0.000)\end{array}$ & & & & \\
\hline U.S. FCI $(\operatorname{lag}=3)$ & $\begin{array}{c}-0.1480^{*-\pi} \\
(0.004)\end{array}$ & $\begin{array}{c}-0.1169^{\star *} \\
(0.029)\end{array}$ & $\begin{array}{c}-0.1716^{\star x-\pi} \\
(0.002)\end{array}$ & $\begin{array}{c}-0.1572^{\star *-\hbar} \\
(0.003)\end{array}$ & & & & \\
\hline Commodity Price Inflation (lag=1) & $\begin{array}{c}-0.5182^{\text {*het }} \\
(0.003)\end{array}$ & $\begin{array}{c}-0.4494^{* * \hbar} \\
(0.009)\end{array}$ & $\begin{array}{c}-0.5072^{\text {*k-k }} \\
(0.003)\end{array}$ & $\begin{array}{c}-0.5251^{*-*} \\
(0.003)\end{array}$ & $\begin{array}{c}-0.3809 \\
(0.111)\end{array}$ & $\begin{array}{c}-0.2618 \\
(0.256)\end{array}$ & $\begin{array}{c}-0.4300^{*} \\
(0.069)\end{array}$ & $\begin{array}{c}-0.4094^{*} \\
(0.089)\end{array}$ \\
\hline Global Growth (lag=1) & $\begin{array}{c}-0.0321 \\
(0.196)\end{array}$ & $\begin{array}{r}-0.0317 \\
(0.180)\end{array}$ & $\begin{array}{c}-0.0282 \\
(0.226)\end{array}$ & $\begin{array}{r}-0.0328 \\
(0.162)\end{array}$ & $\begin{array}{c}-0.0391 \\
(0.149)\end{array}$ & $\begin{array}{c}-0.0439^{*} \\
(0.083)\end{array}$ & $\begin{array}{c}-0.0306 \\
(0.244)\end{array}$ & $\begin{array}{c}-0.0380 \\
(0.145)\end{array}$ \\
\hline Capital Account Openness & $\begin{array}{c}-0.0635 \\
(0.327)\end{array}$ & $\begin{array}{r}-0.0926 \\
(0.165)\end{array}$ & $\begin{array}{c}-0.0626 \\
(0.347)\end{array}$ & $\begin{array}{c}-0.0745 \\
(0.252)\end{array}$ & $\begin{array}{c}-0.0642 \\
(0.323)\end{array}$ & $\begin{array}{c}-0.0922 \\
(0.170)\end{array}$ & $\begin{array}{c}-0.0638 \\
(0.338)\end{array}$ & $\begin{array}{c}-0.0753 \\
(0.247)\end{array}$ \\
\hline Capital Account Openness X U.S. FCI & $\begin{array}{r}-0.0313 \\
(0.405)\end{array}$ & $\begin{array}{l}-0.0265 \\
(0.458)\end{array}$ & $\begin{array}{l}-0.0241 \\
(0.508)\end{array}$ & $\begin{array}{r}-0.0153 \\
(0.701)\end{array}$ & $\begin{array}{r}-0.0308 \\
(0.413)\end{array}$ & $\begin{array}{c}-0.0261 \\
(0.467)\end{array}$ & $\begin{array}{c}-0.0236 \\
(0.517)\end{array}$ & $\begin{array}{c}-0.0148 \\
(0.711)\end{array}$ \\
\hline FDI Linkages with the U.S. & $\begin{array}{c}0.0331^{\text {*nk }} \\
(0.000)\end{array}$ & $\begin{array}{c}0.0294^{* * *} \\
(0.000)\end{array}$ & $\begin{array}{c}0.0336^{\star \star * *} \\
(0.000)\end{array}$ & $\begin{array}{c}0.0319^{\text {*** }} \\
(0.000)\end{array}$ & $\begin{array}{c}0.0331^{* * *} \\
(0.000)\end{array}$ & $\begin{array}{c}0.0294^{\star * \star *} \\
(0.000)\end{array}$ & $\begin{array}{c}0.0336^{*-*} \\
(0.000)\end{array}$ & $\begin{array}{c}0.0319^{*-\pi k} \\
(0.000)\end{array}$ \\
\hline FDI Linkages with the U.S. X U.S. FCI & $\begin{array}{c}0.0047^{\text {** }} \\
(0.022)\end{array}$ & $\begin{array}{c}0.0041^{*} \\
(0.058)\end{array}$ & $\begin{array}{c}0.0052^{\star \star} \\
(0.017)\end{array}$ & $\begin{array}{c}0.0052^{\text {** }} \\
(0.018)\end{array}$ & $\begin{array}{c}0.0047^{\star *} \\
(0.021)\end{array}$ & $\begin{array}{c}0.0041^{*} \\
(0.054)\end{array}$ & $\begin{array}{c}0.0052^{\text {*k}} \\
(0.017)\end{array}$ & $\begin{array}{c}0.0052^{* \star} \\
(0.017)\end{array}$ \\
\hline Trade Link with the U.S. & $\begin{array}{l}0.0145 \\
(0.628)\end{array}$ & & $\begin{array}{l}0.0199 \\
(0.500)\end{array}$ & $\begin{array}{l}0.0227 \\
(0.467)\end{array}$ & $\begin{array}{l}0.0153 \\
(0.611)\end{array}$ & & $\begin{array}{l}0.0205 \\
(0.490)\end{array}$ & $\begin{array}{l}0.0234 \\
(0.454)\end{array}$ \\
\hline Trade Link with the U.S. X U.S. FCI & $\begin{array}{l}0.0086 \\
(0.216)\end{array}$ & & $\begin{array}{l}0.0070 \\
(0.327)\end{array}$ & $\begin{array}{l}0.0071 \\
(0.301)\end{array}$ & $\begin{array}{l}0.0085 \\
(0.215)\end{array}$ & & $\begin{array}{l}0.0070 \\
(0.322)\end{array}$ & $\begin{array}{l}0.0071 \\
(0.300)\end{array}$ \\
\hline Trade Openness & & $\begin{array}{c}0.0077^{*} \\
(0.079)\end{array}$ & & & & $\begin{array}{c}0.0077^{*} \\
(0.079)\end{array}$ & & \\
\hline Trade Openness X U.S. FCI & & $\begin{array}{c}0.0022^{\text {** }} \\
(0.010)\end{array}$ & & & & $\begin{array}{c}0.0022^{\text {k-k}} \\
(0.010)\end{array}$ & & \\
\hline Rule of Law Index & $\begin{array}{c}-0.6298 \\
(0.130)\end{array}$ & $\begin{array}{l}-0.5216 \\
(0.213)\end{array}$ & $\begin{array}{c}-0.6044 \\
(0.145)\end{array}$ & $\begin{array}{c}-0.4886 \\
(0.229)\end{array}$ & $\begin{array}{c}-0.6286 \\
(0.131)\end{array}$ & $\begin{array}{l}-0.5222 \\
(0.213)\end{array}$ & $\begin{array}{c}-0.6021 \\
(0.147)\end{array}$ & $\begin{array}{c}-0.4870 \\
(0.230)\end{array}$ \\
\hline Rule of Law Index X U.S. FCI & $\begin{array}{l}0.0873 \\
(0.112)\end{array}$ & $\begin{array}{l}0.0528 \\
(0.301)\end{array}$ & $\begin{array}{l}0.0813 \\
(0.145)\end{array}$ & $\begin{array}{l}0.0772 \\
(0.183)\end{array}$ & $\begin{array}{l}0.0866 \\
(0.114)\end{array}$ & $\begin{array}{l}0.0529 \\
(0.297)\end{array}$ & $\begin{array}{l}0.0805 \\
(0.149)\end{array}$ & $\begin{array}{l}0.0764 \\
(0.187)\end{array}$ \\
\hline Financial Development Index & $\begin{array}{l}0.0049 \\
(0.994)\end{array}$ & $\begin{array}{l}-0.4410 \\
(0.558)\end{array}$ & $\begin{array}{c}-0.0299 \\
(0.966)\end{array}$ & $\begin{array}{r}-0.0095 \\
(0.989)\end{array}$ & $\begin{array}{l}-0.0004 \\
(1.000)\end{array}$ & $\begin{array}{c}-0.4571 \\
(0.547)\end{array}$ & $\begin{array}{c}-0.0298 \\
(0.966)\end{array}$ & $\begin{array}{l}-0.0128 \\
(0.985)\end{array}$ \\
\hline Financial Development Index X U.S. FCI & $\begin{array}{c}-0.6577^{\star-\kappa *} \\
(0.005)\end{array}$ & $\begin{array}{c}-0.5474^{* *} \\
(0.010)\end{array}$ & $\begin{array}{c}-0.5985^{\text {*k }} \\
(0.019)\end{array}$ & $\begin{array}{c}-0.6444^{\text {***k}} \\
(0.008)\end{array}$ & $\begin{array}{c}-0.6574^{* \star * * *} \\
(0.004)\end{array}$ & $\begin{array}{c}-0.5523^{\text {thet }} \\
(0.009)\end{array}$ & $\begin{array}{c}-0.5946^{* k} \\
(0.020)\end{array}$ & $\begin{array}{c}-0.6425^{\text {*k*k}} \\
(0.008)\end{array}$ \\
\hline Exchange Rate Stability Index & & & $\begin{array}{c}-0.3965^{*} \\
(0.081)\end{array}$ & & & & $\begin{array}{c}-0.3913^{*} \\
(0.083)\end{array}$ & \\
\hline Exchange Rate Stability Index X U.S. FCI & & & $\begin{array}{c}-0.1203 \\
(0.376)\end{array}$ & & & & $\begin{array}{l}-0.1207 \\
(0.368)\end{array}$ & \\
\hline Exchange Rate Flexibility & & & & $\begin{array}{c}0.1986^{\star \star \star *} \\
(0.007)\end{array}$ & & & & $\begin{array}{c}0.1983^{\text {*** }} \\
(0.007)\end{array}$ \\
\hline Exchange Rate Flexibility X U.S. FCI & & & & $\begin{array}{l}0.0503 \\
(0.224)\end{array}$ & & & & $\begin{array}{l}0.0506 \\
(0.221) \\
\end{array}$ \\
\hline Observations & 6,920 & 6,906 & 6,920 & 6,920 & 6,920 & 6,906 & 6,920 & 6,920 \\
\hline$R$-squared & 0.428 & 0.438 & 0.432 & 0.438 & 0.425 & 0.434 & 0.429 & 0.435 \\
\hline Number of Countries & 39 & 39 & 39 & 39 & 39 & 39 & 39 & 39 \\
\hline
\end{tabular}

Source: Authors' estimates.

Note: Robust $p$-values in parentheses. $\mathrm{FCl}=$ financial conditions index, FDI = foreign direct investments. ${ }^{* * *} p<0.01,{ }^{* *} p<0.05$, ${ }^{*} \mathrm{p}<0.1$. 


\section{Table 3. Robustness: Determinants of Sensitivity to Global Financial Conditions}

\begin{tabular}{|c|c|c|c|c|c|c|c|c|}
\hline & (1) & (2) & (3) & (4) & (5) & (6) & (7) & (8) \\
\hline U.S. FCI (lag =0) & $\begin{array}{c}0.4019^{* * * *} \\
(0.000)\end{array}$ & $\begin{array}{c}0.4156^{* * *} \\
(0.000)\end{array}$ & $\begin{array}{c}0.4092^{* * * *} \\
(0.000)\end{array}$ & $\begin{array}{c}0.3709^{* * *} \\
(0.000)\end{array}$ & $\begin{array}{c}0.3808^{* * * *} \\
(0.000)\end{array}$ & $\begin{array}{c}0.3555^{* * * *} \\
(0.000)\end{array}$ & $\begin{array}{c}0.3838 * * * \\
(0.000)\end{array}$ & $\begin{array}{c}0.3296^{* * *} \\
(0.000)\end{array}$ \\
\hline Real Growth (lag=1) & $\begin{array}{c}-0.0903^{* * *} \\
(0.000)\end{array}$ & $\begin{array}{c}-0.0910^{* * * *} \\
(0.000)\end{array}$ & $\begin{array}{c}*-0.0897^{* * *} \\
(0.000)\end{array}$ & $\begin{array}{c}*-0.0920 * * * \\
(0.000)\end{array}$ & $\begin{array}{c}-0.0915^{* * *} \\
(0.000)\end{array}$ & $\begin{array}{c}* 0.0940^{* * * *} \\
(0.000)\end{array}$ & $\begin{array}{c}*-0.0916^{* * * *} \\
(0.000)\end{array}$ & $\begin{array}{c}-0.0954^{* * * *} \\
(0.000)\end{array}$ \\
\hline Inflation (lag=1) & $\begin{array}{c}0.0212^{* * *} \\
(0.000)\end{array}$ & $\begin{array}{c}0.0211^{* * *} \\
(0.000)\end{array}$ & $\begin{array}{c}0.0224^{* * *} \\
(0.000)\end{array}$ & $\begin{array}{c}0.0219^{* * * *} \\
(0.000)\end{array}$ & $\begin{array}{c}0.0215^{* * *} \\
(0.000)\end{array}$ & $\begin{array}{c}0.0217^{* * * *} \\
(0.000)\end{array}$ & $\begin{array}{c}0.0216^{* * *} \\
(0.000)\end{array}$ & $\begin{array}{c}-0.0001 \\
(0.716)\end{array}$ \\
\hline Current Account Balance to GDP $(\operatorname{lag}=1)$ & $\begin{array}{l}0.0045 \\
(0.781)\end{array}$ & $\begin{array}{l}0.0052 \\
(0.751)\end{array}$ & $\begin{array}{l}0.0053 \\
(0.745)\end{array}$ & $\begin{array}{l}0.0044 \\
(0.785)\end{array}$ & $\begin{array}{l}0.0037 \\
(0.819)\end{array}$ & $\begin{array}{l}0.0029 \\
(0.858)\end{array}$ & $\begin{array}{l}0.0034 \\
(0.833)\end{array}$ & $\begin{array}{r}0.0042 \\
(0.748)\end{array}$ \\
\hline Commodity Price Inflation (lag=1) & $\begin{array}{c}-0.5017^{* * *} \\
(0.045)\end{array}$ & $\begin{array}{c}-0.5266^{* *} \\
(0.046)\end{array}$ & $\begin{array}{c}-0.4199^{*} \\
(0.096)\end{array}$ & $\begin{array}{c}-0.4838^{*} \\
(0.086)\end{array}$ & $\begin{array}{c}-0.4557^{* *} \\
(0.048)\end{array}$ & $\begin{array}{c}-0.5050^{*} \\
(0.063)\end{array}$ & $\begin{array}{c}-0.4105^{*} \\
(0.086)\end{array}$ & $\begin{array}{c}-0.5594^{* * *} \\
(0.002)\end{array}$ \\
\hline Global Growth (lag=1) & $\begin{array}{c}-0.0326 \\
(0.259)\end{array}$ & $\begin{array}{c}-0.0337 \\
(0.247)\end{array}$ & $\begin{array}{c}-0.0388 \\
(0.178)\end{array}$ & $\begin{array}{c}-0.0360 \\
(0.206)\end{array}$ & $\begin{array}{r}-0.0354 \\
(0.208)\end{array}$ & $\begin{array}{r}-0.0322 \\
(0.261)\end{array}$ & $\begin{array}{c}-0.0350 \\
(0.233)\end{array}$ & $\begin{array}{c}-0.0284 \\
(0.272)\end{array}$ \\
\hline Capital Account Openness & $\begin{array}{c}-0.0204 \\
(0.810)\end{array}$ & $\begin{array}{c}-0.0202 \\
(0.814)\end{array}$ & $\begin{array}{r}-0.0482 \\
(0.598)\end{array}$ & $\begin{array}{c}-0.0302 \\
(0.726)\end{array}$ & $\begin{array}{c}-0.0209 \\
(0.806)\end{array}$ & $\begin{array}{c}-0.0140 \\
(0.864)\end{array}$ & $\begin{array}{c}-0.0292 \\
(0.724)\end{array}$ & $\begin{array}{c}-0.0694 \\
(0.292)\end{array}$ \\
\hline Capital Account Openness X U.S. FCI & $\begin{array}{r}-0.0549 \\
(0.159)\end{array}$ & $\begin{array}{c}-0.0581 \\
(0.125)\end{array}$ & $\begin{array}{c}-0.0593 \\
(0.147)\end{array}$ & $\begin{array}{c}-0.0534 \\
(0.176)\end{array}$ & $\begin{array}{r}-0.0501 \\
(0.209)\end{array}$ & $\begin{array}{r}-0.0467 \\
(0.282)\end{array}$ & $\begin{array}{c}-0.0563 \\
(0.150)\end{array}$ & $\begin{array}{c}-0.0218 \\
(0.566)\end{array}$ \\
\hline FDI Linkages with the U.S. & $\begin{array}{c}0.0324^{* * *} \\
(0.000)\end{array}$ & $\begin{array}{c}0.0324^{* * * *} \\
(0.000)\end{array}$ & $\begin{array}{c}0.0315^{* * *} \\
(0.000)\end{array}$ & $\begin{array}{c}0.0325^{* * *} \\
(0.000)\end{array}$ & $\begin{array}{c}0.0323^{* * *} \\
(0.000)\end{array}$ & $\begin{array}{c}0.0317^{* * * *} \\
(0.000)\end{array}$ & $\begin{array}{c}0.0326^{* * *} \\
(0.000)\end{array}$ & $\begin{array}{c}0.0324^{* * *} \\
(0.000)\end{array}$ \\
\hline FDI Linkages with the U.S. X U.S. FCI & $\begin{array}{c}0.0058^{* * * *} \\
(0.006)\end{array}$ & $\begin{array}{c}0.0057^{* * *} \\
(0.005)\end{array}$ & $\begin{array}{c}0.0058^{* * *} \\
(0.003)\end{array}$ & $\begin{array}{c}0.0056^{* * *} \\
(0.003)\end{array}$ & $\begin{array}{c}0.0058^{* * * *} \\
(0.005)\end{array}$ & $\begin{array}{c}0.0056^{* * *} \\
(0.005)\end{array}$ & $\begin{array}{c}0.0053^{* * *} \\
(0.006)\end{array}$ & $\begin{array}{c}0.0058^{* *} \\
(0.010)\end{array}$ \\
\hline Trade Link with the U.S. & $\begin{array}{l}0.0130 \\
(0.671)\end{array}$ & $\begin{array}{l}0.0120 \\
(0.698)\end{array}$ & $\begin{array}{l}0.0192 \\
(0.523)\end{array}$ & $\begin{array}{l}0.0135 \\
(0.669)\end{array}$ & $\begin{array}{l}0.0129 \\
(0.675)\end{array}$ & $\begin{array}{l}0.0109 \\
(0.732)\end{array}$ & $\begin{array}{l}0.0140 \\
(0.659)\end{array}$ & $\begin{array}{r}0.0186 \\
(0.551)\end{array}$ \\
\hline Trade Link with the U.S. $X$ U.S. FCI & $\begin{array}{l}0.0093 \\
(0.135)\end{array}$ & $\begin{array}{l}0.0088 \\
(0.135)\end{array}$ & $\begin{array}{l}0.0099 \\
(0.115)\end{array}$ & $\begin{array}{l}0.0088 \\
(0.162)\end{array}$ & $\begin{array}{l}0.0095 \\
(0.138)\end{array}$ & $\begin{array}{l}0.0085 \\
(0.168)\end{array}$ & $\begin{array}{l}0.0112 \\
(0.117)\end{array}$ & $\begin{array}{r}0.0062 \\
(0.366)\end{array}$ \\
\hline Rule of Law Index & $\begin{array}{c}-0.4753 \\
(0.246)\end{array}$ & $\begin{array}{c}-0.4625 \\
(0.256)\end{array}$ & $\begin{array}{c}-0.4364 \\
(0.297)\end{array}$ & $\begin{array}{c}-0.4691 \\
(0.239)\end{array}$ & $\begin{array}{l}-0.4900 \\
(0.224)\end{array}$ & $\begin{array}{c}-0.4651 \\
(0.231)\end{array}$ & $\begin{array}{l}-0.4682 \\
(0.234)\end{array}$ & $\begin{array}{l}-0.6291 \\
(0.131)\end{array}$ \\
\hline Rule of Law Index X U.S. FCI & $\begin{array}{c}0.1102^{* *} \\
(0.040)\end{array}$ & $\begin{array}{l}0.0931^{*} \\
(0.076)\end{array}$ & $\begin{array}{c}0.1145^{* *} \\
(0.046)\end{array}$ & $\begin{array}{l}0.0715 \\
(0.191)\end{array}$ & $\begin{array}{l}0.0851 \\
(0.213)\end{array}$ & $\begin{array}{l}0.0399 \\
(0.567)\end{array}$ & $\begin{array}{l}0.1165 \\
(0.116)\end{array}$ & $\begin{array}{r}0.0801 \\
(0.147)\end{array}$ \\
\hline Financial Development Index & $\begin{array}{r}-0.0473 \\
(0.947)\end{array}$ & & & & & & & $\begin{array}{c}-0.0747 \\
(0.918)\end{array}$ \\
\hline Financial Development Index X U.S. FCI & $\begin{array}{c}-0.4066^{*} \\
(0.088)\end{array}$ & & & & & & & $\begin{array}{c}-0.5989^{* *} \\
(0.012)\end{array}$ \\
\hline Financial Development Index: Financial Markets & & $\begin{array}{l}-0.0516 \\
(0.925)\end{array}$ & & & & & & \\
\hline Financial Development Index: Finan cial Markets X U.S. FCI & & $\begin{array}{c}-0.3418^{*} \\
(0.067)\end{array}$ & & & & & & \\
\hline Financial Development Index: Financial Markets Depth & & & $\begin{array}{l}0.5199 \\
(0.175)\end{array}$ & & & & & \\
\hline Financial Development Index: Financial Markets Depth X U.S. FCI & & & $\begin{array}{c}-0.2788^{*} \\
(0.069)\end{array}$ & & & & & \\
\hline Financial Development Index: Financial Markets Efficiency & & & & $\begin{array}{l}0.0919 \\
(0.806)\end{array}$ & & & & \\
\hline Financial Development Index: Financial Markets Efficiency X U.S. FCI & & & & $\begin{array}{l}-0.0542 \\
(0.636)\end{array}$ & & & & \\
\hline Financial Development Index: Financial Institutions & & & & & $\begin{array}{l}-0.0170 \\
(0.982)\end{array}$ & & & \\
\hline Financial Development Index: Finan cial Institutions X U.S. FCI & & & & & $\begin{array}{l}-0.1636 \\
(0.583)\end{array}$ & & & \\
\hline Financial Development Index: Financial Institutions Depth & & & & & & $\begin{array}{l}-0.5732 \\
(0.409)\end{array}$ & & \\
\hline Financial Development Index: Financial Institutions Depth X U.S. FCI & & & & & & $\begin{array}{l}0.0886 \\
(0.623)\end{array}$ & & \\
\hline Financial Development Index: Financial Institutions Efficiency & & & & & & & $\begin{array}{l}0.4188 \\
(0.624)\end{array}$ & \\
\hline Financial Development Index: Finan cial Institutions Efficiency X U.S. FCI & & & & & & & $\begin{array}{l}-0.4726 \\
(0.149)\end{array}$ & \\
\hline Bank Linkages with the U.S. & $\begin{array}{l}0.0107 \\
(0.685)\end{array}$ & $\begin{array}{l}0.0100 \\
(0.701)\end{array}$ & $\begin{array}{l}0.0093 \\
(0.719)\end{array}$ & $\begin{array}{l}0.0085 \\
(0.744)\end{array}$ & $\begin{array}{l}0.0101 \\
(0.706)\end{array}$ & $\begin{array}{l}0.0101 \\
(0.700)\end{array}$ & $\begin{array}{l}0.0097 \\
(0.716)\end{array}$ & \\
\hline Bank Linkages with the U.S. X U.S. FCI & $\begin{array}{l}-0.0038 \\
(0.602)\end{array}$ & $\begin{array}{l}-0.0034 \\
(0.635)\end{array}$ & $\begin{array}{r}-0.0043 \\
(0.530)\end{array}$ & $\begin{array}{c}-0.0052 \\
(0.410)\end{array}$ & $\begin{array}{l}-0.0052 \\
(0.452)\end{array}$ & $\begin{array}{c}-0.0059 \\
(0.359)\end{array}$ & $\begin{array}{c}-0.0072 \\
(0.276)\end{array}$ & \\
\hline Portfolio Linkages with the U.S. & & & & & & & & $\begin{array}{l}0.0008 \\
(0.515)\end{array}$ \\
\hline Portfolio Linkages with the U.S. X U.S. FCI & & & & & & & & $\begin{array}{r}-0.0005 \\
(0.357)\end{array}$ \\
\hline U.S. FCI $(\operatorname{lag}=1)$ & & & & & & & & $\begin{array}{l}0.0479 \\
(0.260)\end{array}$ \\
\hline U.S. FCI $(\mathrm{lag}=2)$ & & & & & & & & $\begin{array}{c}0.2474^{* * *} \\
(0.000)\end{array}$ \\
\hline U.S. FCI (lag=3) & & & & & & & & $\begin{array}{c}-0.1641^{* * *} \\
(0.001)\end{array}$ \\
\hline Observations & 6,455 & 6,455 & 6,455 & 6,455 & 6,455 & 6,455 & 6,455 & 6,705 \\
\hline R-squared & 0.418 & 0.419 & 0.420 & 0.415 & 0.415 & 0.416 & 0.417 & 0.422 \\
\hline Number of countrycode & 37 & 37 & 37 & 37 & 37 & 37 & 37 & 38 \\
\hline
\end{tabular}

Source: Authors' estimates.

Note: Robust $p$-values in parentheses. $\mathrm{FCl}=$ financial conditions index, $\mathrm{FDI}=$ foreign direct investments. ${ }^{* * *} \mathrm{p}<0.01,{ }^{* *} p<0.05$, ${ }^{*} \mathrm{p}<0.1$. 


\section{Can Countries Manage Domestic Financial Conditions Amid Global FINANCIAL INTEGRATION?}

This section quantifies the relative share of fluctuations in countries' domestic financial conditions explained by global financial conditions and domestic monetary policy. It finds that despite the importance of global financial shocks, monetary policy still accounts for a notable share of the variation in domestic financial conditions.

\section{A. Transmission of Global Financial and Domestic Monetary Policy Shocks to Domestic FCIs}

The study of the transmission of domestic monetary policy and global financial conditions to domestic financial conditions is based on panel vector autoregressive (panel VAR) models. The baseline system includes the U.S. financial conditions index (FCI) - again, a proxy for global financial conditions - as well as growth, inflation, domestic FCI, and the change in domestic monetary policy. Growth is measured by the change in industrial production, and inflation is computed using the consumer price index. Monetary policy is measured with a monetary-policy-related interest rate (usually a central bank discount rate or a short-term money market rate). The sample consists of 25 small open economies with flexible exchange rate regimes, with monthly data from 2001 to 2016 . The baseline model takes the following form:

$$
\begin{aligned}
& Y_{c, t}=A Y_{c, t-1}+B X_{t}+\varepsilon_{c, t} \\
& Y_{c, t}=\left[\begin{array}{lllll}
F C I_{t}^{*} & \Delta I P_{c, t} & \Delta C P I_{c, t} & F C I_{c, t} & \Delta i_{c, t}
\end{array}\right]^{T}
\end{aligned}
$$

in which $\Delta I P_{c, t}, \Delta C P I_{c, t}, \Delta i_{c, t}, F C I_{t}^{*}$, and $F C I_{c, t}$ denote (log) industrial production growth, inflation (based on log CPI), the change in domestic policy rates, and the U.S. and country-specific FCIs (for country $c$ in month $t$ ) respectively; $X_{t}$ is added for robustness analysis, and includes various global controls including global industrial production growth, commodity prices, and a measure of global interest rates (proxied, for example, using several U.S. shadow rate measures). The baseline panel VAR is estimated with four lags using Pesaran, Shin, and Smith's (1999) mean group estimator, which is consistent in the presence of dynamic heterogeneity. Impulse responses are drawn from Cholesky decompositions under the assumption that domestic interest rates move last and the U.S. FCI moves first. All standard errors are estimated using a nonparametric bootstrap and 1,000 replications. ${ }^{21}$ For additional insight, VAR models are also estimated individually for each country using the same set of variables (and, for example, global controls including commodity prices and world industrial production growth).

Confirming the previous findings discussed in the paper and in other studies, the results based on panel VAR models indicate that global financial shocks have a notable impact on countries' domestic financial conditions (Figure 9). A one standard deviation tightening in global financial conditions (again, proxied with the U.S. FCI) raises domestic financial

\footnotetext{
${ }^{21}$ To compare results according to countries' financial openness, an analogous exercise is conducted splitting the sample into two groups based on their relative capital account openness (as measured by the Chinn-Ito index).
} 
conditions by, on average, about one-fifth of a standard deviation across the small open economies with flexible exchange rates in the sample. However, changes in local policy rates also have an appreciable effect on local FCIs. Notably, it appears that local financial conditions react faster and more strongly to global financial shocks than to changes in domestic policy rates, suggesting that timely and effective monetary policy reactions may often be difficult. For example, if monetary policy is intended to offset an unwelcome global shock, it may have to react very quickly and strongly, with potentially undesirable side effects.

Figure 9. Response of Domestic Financial Conditions to Shocks (In percent, standard deviations)

-Monetary policy shocks _ Global financial shocks

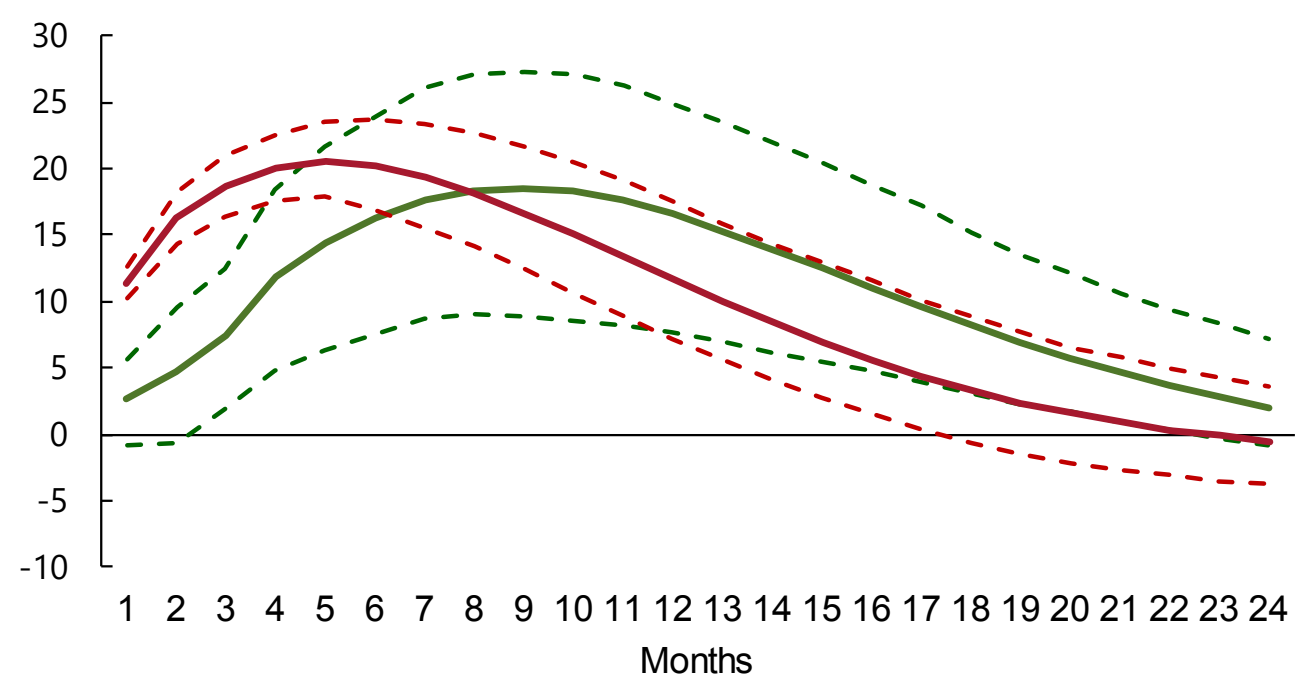

Source: Authors' estimates.

Note: The figure displays the impulse response functions (based on a panel VAR model) and 90 percent confidence bands of domestic FCls to global financial or domestic monetary policy shocks for countries in the sample with flexible exchange rates.

These results are generally robust to alternative lag specifications, to the inclusion of various combinations of global controls (global industrial production growth, commodity prices, and a measure of global interest rates), and, for instance, to using the level of the variables. The results do not change when exchange rate terms are added into the panel VAR (Table 4). 
Table 4. Summary: Panel VAR Robustness: Impulse Response of Domestic FCl to Selected Shocks

\begin{tabular}{|c|c|c|c|c|}
\hline \multirow[b]{2}{*}{ Variables Added to Baseline } & \multicolumn{2}{|c|}{ Monetary Policy Shock } & \multicolumn{2}{|c|}{ Global Financial Shock } \\
\hline & $\begin{array}{c}\text { Peak } \\
\text { Magnitude } \\
\text { (In percent, } \\
\text { standard } \\
\text { deviations) }\end{array}$ & $\begin{array}{l}\text { Time to } \\
\text { Peak } \\
\text { (Months) }\end{array}$ & $\begin{array}{c}\text { Peak } \\
\text { Magnitude } \\
\text { (In percent, } \\
\text { standard } \\
\text { deviations) }\end{array}$ & $\begin{array}{l}\text { Time to } \\
\text { Peak } \\
\text { (Months) }\end{array}$ \\
\hline Exog: commodity price inflation & 16.5 & 8 & 15.6 & 5 \\
\hline $\begin{array}{l}\text { Exog: commodity price inflation growth in } \\
\text { global IP, change in U.S. shadow rate } \\
\text { (Xia Wu) }\end{array}$ & 14.8 & 9 & 15.7 & 6 \\
\hline $\begin{array}{l}\text { Exog: commodity price inflation, growth in } \\
\text { global IP, change in U.S. shadow rate } \\
\text { (Krippner) }\end{array}$ & 14.0 & 9 & 15.2 & 6 \\
\hline Endog: change in NEER & 15.4 & 9 & 20.1 & 5 \\
\hline Endog: change in REER & 15.5 & 9 & 20.3 & 5 \\
\hline $\begin{array}{l}\text { Endog: change in bilateral exchange rate } \\
\text { with the U.S. }\end{array}$ & 15.4 & 9 & 20.5 & 5 \\
\hline
\end{tabular}

Source: Authors' estimates.

Note: Exog = exogenous; Endog = endogenous.

The average responses from VAR models estimated for individual countries result in broadly similar findings (see Table 5 which summarizes the robustness analysis which was conducted). Complementary methods of identifying the monetary policy shocks are discussed later in this section. 
Table 5. Summary: Individual Country VAR Robustness: Impulse Response of Domestic FCl to Selected Shocks

(In percent, standard deviations)

\begin{tabular}{|c|c|c|c|}
\hline & $\begin{array}{l}\text { Impulse Response } \\
\text { Function: World FCl }\end{array}$ & $\begin{array}{l}\text { Impulse Response Function: } \\
\text { Domestic Policy Rate }\end{array}$ & $\begin{array}{c}\text { Impulse Response Function: } \\
\text { Domestic FCl }\end{array}$ \\
\hline \multicolumn{4}{|c|}{ Small Open Advanced Economies } \\
\hline Baseline specification & 15.3 & 9.4 & 19.9 \\
\hline Short specification & 11.9 & 9.7 & 17.7 \\
\hline Long specification & 12.9 & 9.4 & 14.3 \\
\hline \multicolumn{4}{|l|}{ Emerging Markets } \\
\hline Baseline specification & 16.3 & 6.3 & 17.3 \\
\hline Short specification & 12.0 & 6.1 & 14.4 \\
\hline \multirow[t]{2}{*}{ Long specification } & 13.9 & 4.5 & 11.6 \\
\hline & $\begin{array}{l}\text { Impulse Response } \\
\text { Function: World FCl }\end{array}$ & $\begin{array}{l}\text { Impulse Response Function: } \\
\text { Domestic Policy Rate }\end{array}$ & $\begin{array}{c}\text { Impulse Response Function: } \\
\text { Domestic FCl }\end{array}$ \\
\hline \multicolumn{4}{|c|}{ Small Open Advanced Economies } \\
\hline 1-quarter lag & 8.4 & 7.0 & 14.4 \\
\hline 3-quarter lag & 12.0 & 8.8 & 14.5 \\
\hline 4-quarter lag & 11.7 & 9.3 & 13.8 \\
\hline 6-quarter lag & 11.1 & 9.5 & 13.2 \\
\hline \multicolumn{4}{|l|}{ Emerging Markets } \\
\hline 1-quarter lag & 10.1 & 4.1 & 11.4 \\
\hline 3-quarter lag & 12.1 & 4.3 & 11.8 \\
\hline 4-quarter lag & 13.0 & 4.6 & 11.7 \\
\hline 6-quarter lag & 13.6 & 4.8 & 11.4 \\
\hline
\end{tabular}

Source: Authors' estimates.

Note: This table summarizes the peak impulse response functions to selected shocks for different model specifications (including country sample and lags). Baseline corresponds to VAR models including (in order): global $\mathrm{FCl}$, (log) industrial production (IP), (log) consumer price index (CPI), domestic $\mathrm{FCl}$ and policy rate. The short specification excludes IP and CPI, whereas the long specification adds global commodity index and global IP index. 


\section{B. Share of Domestic FCI Fluctuations Attributable to Global Financial and Domestic Monetary Policy Shocks}

Using the VAR models discussed previously, we employ variance decompositions to quantify the relative importance of shocks on domestic financial conditions.

The results confirm that a considerable share of domestic FCI fluctuations is attributed to global financial conditions and domestic policy rates. On average, about 21 percent of the variation in domestic FCIs across small open economies with flexible exchange rates is attributed to global financial shocks (Figure 10). This implies that the remainder is explained by domestic factors, including shocks originating from the local financial sector. Importantly, domestic monetary policy shocks account for about 15 percent of the fluctuations in FCIs. The results are broadly robust to other panel VAR specifications (see Table 6 for a summary).

Figure 10. Share of Domestic Financial Conditions Index Fluctuations Attributable to Global Financial and Monetary Policy Shocks

(In percent)

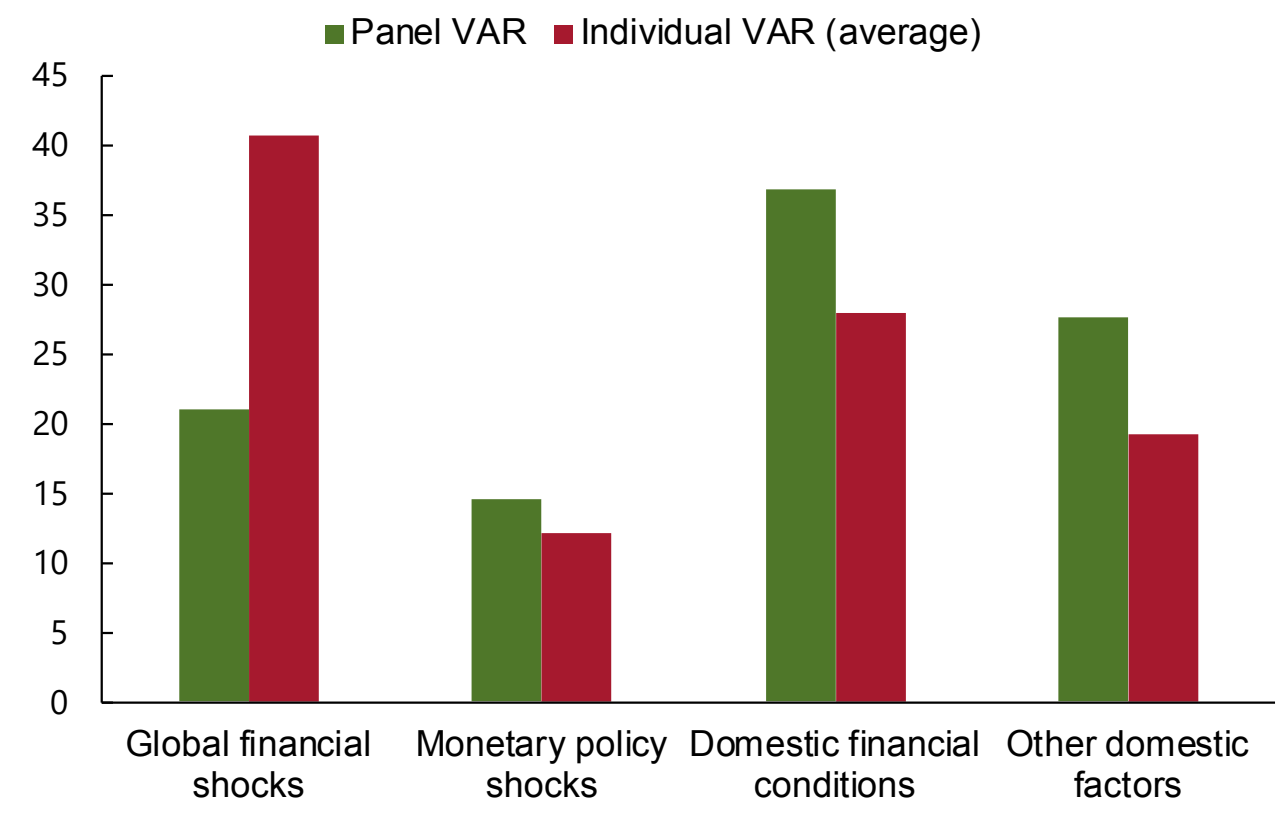

Source: Authors' estimates.

Note: The figure displays the share of domestic FCl fluctuations accounted for by global financial, domestic monetary policy, or domestic financial condition shocks, and shocks associated with other domestic factors for countries in the sample with flexible exchange rates. It is based on the panel VAR model or on VAR models estimated individually for each country. See text for details. $\mathrm{FCl}=$ financial conditions index; VAR = vector autoregression.

Moreover, complementary analysis, in which a similar VAR model is estimated for each country individually, indicates that shocks to global financial conditions and to monetary 
policy account for, on average, about 40 percent and 12 percent of countries' domestic FCI variations, respectively. For both models, the variance decompositions are statistically significant at the 10 percent level. Robustness exercises that control for global growth and commodity prices and, for instance, various lag lengths, yield broadly similar results (see Table 7 for a summary).

Table 6. Summary Panel VAR Robustness: Share of Domestic FCI Variation Attributable to Selected Shocks (In percent)

\begin{tabular}{|c|c|c|c|}
\hline & \multicolumn{3}{|c|}{ Variance Decomposition } \\
\hline Variables Added to Baseline & $\begin{array}{c}\text { Global Financial } \\
\text { Conditions }\end{array}$ & Domestic Monetary Policy & Other \\
\hline Exog: commodity price inflation & 15.6 & 15.5 & 68.9 \\
\hline $\begin{array}{l}\text { Exog: commodity price inflation } \\
\text { growth in global IP, change in U.S. } \\
\text { shadow rate } \\
(\text { Xia } W u)\end{array}$ & 16.8 & 11.8 & 71.4 \\
\hline $\begin{array}{l}\text { Exog: commodity price inflation, } \\
\text { growth in global IP, change in U.S. } \\
\text { shadow rate (Krippner) }\end{array}$ & 17.8 & 12.5 & 69.7 \\
\hline Endog: change in NEER & 13.9 & 11.9 & 74.2 \\
\hline Endog: change in REER & 15.1 & 12.6 & 72.3 \\
\hline $\begin{array}{l}\text { Endog: change in bilateral } \\
\text { exchange rate } \\
\text { with the U.S. }\end{array}$ & 14.6 & 12.2 & 73.2 \\
\hline
\end{tabular}

Source: Authors' estimates.

Note: Variance decomposition at a 12-month horizon. 
Table 7. Summary: Individual Country VAR Robustness: Share of Domestic FCl Variation Attributable to Selected Shock (In percent)

\begin{tabular}{|c|c|c|c|}
\hline & $\begin{array}{c}\text { Variance Decomposition } \\
\text { World FCl }\end{array}$ & $\begin{array}{l}\text { Variance Decomposition: } \\
\text { Domestic Policy Rate }\end{array}$ & $\begin{array}{c}\text { Variance Decomposition: } \\
\text { Domestic FCl }\end{array}$ \\
\hline \multicolumn{4}{|l|}{$\begin{array}{l}\text { Small Open Advanced } \\
\text { Economies }\end{array}$} \\
\hline Baseline specification & 26.1 & 20.1 & 28.4 \\
\hline Long specification & 23.0 & 18.0 & 27.9 \\
\hline Short specification & 27.6 & 26.4 & 46.0 \\
\hline \multicolumn{4}{|l|}{ Emerging Markets } \\
\hline Baseline specification & 38.2 & 11.3 & 25.6 \\
\hline Long specification & 36.4 & 10.5 & 24.1 \\
\hline \multirow[t]{2}{*}{ Short specification } & 40.8 & 18.0 & 41.3 \\
\hline & $\begin{array}{c}\text { Variance } \\
\text { Decomposition } \\
\text { World FCl }\end{array}$ & $\begin{array}{l}\text { Variance Decomposition: } \\
\text { Domestic Policy Rate }\end{array}$ & $\begin{array}{c}\text { Variance Decomposition: } \\
\text { Domestic FCl }\end{array}$ \\
\hline \multicolumn{4}{|l|}{$\begin{array}{l}\text { Small Open Advanced } \\
\text { Economies }\end{array}$} \\
\hline 1-quarter lag & 21.8 & 23.4 & 40.8 \\
\hline 3-quarter lag & 26.2 & 22.2 & 35.6 \\
\hline 4-quarter lag & 25.8 & 23.4 & 32.5 \\
\hline 6-quarter lag & 25.0 & 21.1 & 31.1 \\
\hline \multicolumn{4}{|l|}{ Emerging Markets } \\
\hline 1-quarter lag & 31.7 & 14.6 & 35.2 \\
\hline 3-quarter lag & 39.1 & 13.6 & 32.9 \\
\hline 4-quarter lag & 41.2 & 14.1 & 29.5 \\
\hline 6-quarter lag & 38.9 & 13.4 & 27.5 \\
\hline
\end{tabular}

Source: Authors' estimates.

Note: This table summarizes the variance decomposition of each variable of interest under different model specifications (including country sample and lags.) Baseline corresponds to VAR models including (in order): global FCI, (log) industrial production (IP), (log) consumer price index (CPI), domestic $\mathrm{FCl}$ and policy rate. The short specification excludes IP and $\mathrm{CPI}$, whereas the long specification adds global commodity index and global IP index. 


\section{Recognizing Country Heterogeneity}

To investigate the differing impact of global financial conditions on countries' FCIs, this subsection estimates country-by-country VARs (using the baseline specification described earlier). The findings reveal that the importance of global financial shocks for domestic financial conditions varies considerably across countries (Figure 11). Using a broader set of countries, this histogram is broadly bi-modal, with small open advanced economies clustered in the left tail. In fact, global financial conditions generally tend to account for a greater proportion of FCI variability in emerging market economies, and in a few cases, this proportion exceeds 60 percent. Moreover, in line with intuition, the results indicate that fluctuations in global financial conditions are associated with a greater share of FCI variability in countries that are relatively more financially integrated with the rest of the world, and these differences are greater for emerging market economies. In line with the findings discussed previously, these results are also robust to alternative specifications, including VARs which incorporate various measures of commodity prices, global growth, and interest rates.

Figure 11. Share of Domestic Financial Conditions Index Fluctuations Attributable to Global Financial Conditions

(Frequency)

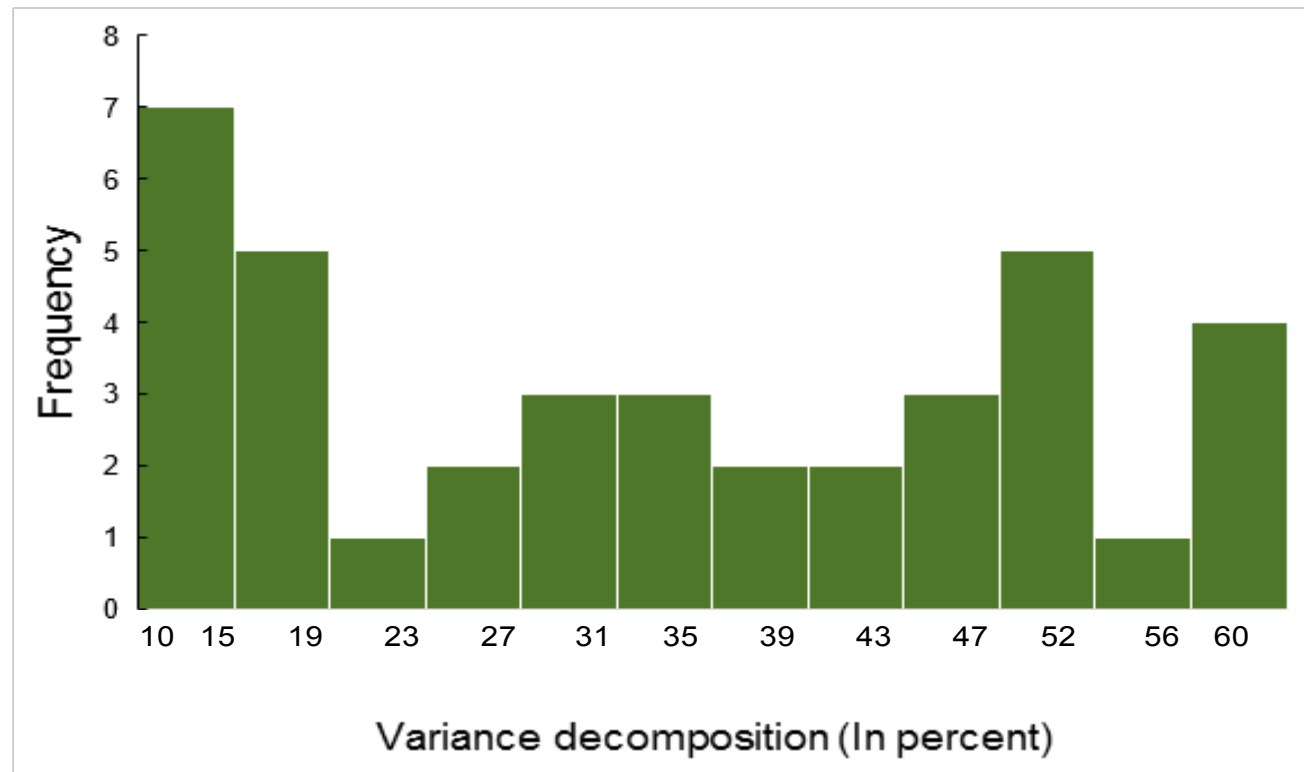

Source: Authors' estimates.

Note: Histogram intervals on the x-axis vary because of rounding. The figure displays the share of fluctuations in domestic financial conditions attributable to global financial shocks based on vector autoregression models estimated individually for all countries in the sample. See text for details. 


\section{A More Refined Approach to Identifying Monetary Policy Shocks}

The identification of shocks can be especially difficult in the context of the VAR models used in this paper, particularly for monetary policy. Because precisely identifying monetary policy shocks is challenging, recent studies have developed methods that help better pinpoint exogenous measures of such shocks. In line with the methodology traced out by Gertler and Karadi (2015), who build on Gürkaynak, Sack, and Swanson (2005), among others, unexpected changes in bond yields on central bank policy announcement dates are used to measure policy surprises. Compared to a standard Cholesky decomposition, their method allows monetary policy and financial variables to influence each other within the same period. Broadly speaking, a three-step procedure, which is a form of instrument variable estimation, is used. First, monetary policy shocks are identified as movements in various interest rates (government securities of different maturities) within a narrow window (for example, 30 minutes) following monetary policy announcement decisions. A monthly monetary policy surprise series is constructed by applying a scaling factor to the highfrequency shocks. Second, these constructed monetary policy surprises are used as regressors (instruments) for the monetary policy indicator (one-year or two-year government bond yields depending on data availability). The fitted values from the regression correspond to changes in the policy indicator attributable to monetary policy shocks. Third, the fitted values from the regression are used in the original VAR to derive the column in the matrix of coefficients corresponding to the monetary policy shock. This allows then to compute impulse responses of all variables to the monetary policy shocks.

Such shocks are derived for Australia, New Zealand, Norway, and Sweden-four small open advanced economies with floating exchange rate regimes and relatively deep financial markets. These four-small open advanced economies were also chosen based on the availability of sufficiently long monthly and daily yields with appropriate terms.

In each of the country cases shown in Figure 12, VAR models using these better-identified monetary policy shocks yield results similar to those examined earlier (which were based on the Cholesky decomposition), lending further credence to the empirical findings discussed in this section. The impulse response functions of domestic financial conditions to domestic monetary policy shocks are very similar and statistically indistinguishable from each other using the Cholesky or the Gertler-Karadi identification methods in each of the four country case studies. $^{22}$

\footnotetext{
22 The share of FCI variation characterized by fluctuations in global financial conditions and domestic monetary policy is, on average 15 percent and 33 percent, respectively, for these four country case studies (based on a Cholesky decomposition).
} 
Figure 12. Selected Advanced Economies: Response of Financial Conditions Index to Monetary Policy Shocks

(Standard deviations)

1. Australia
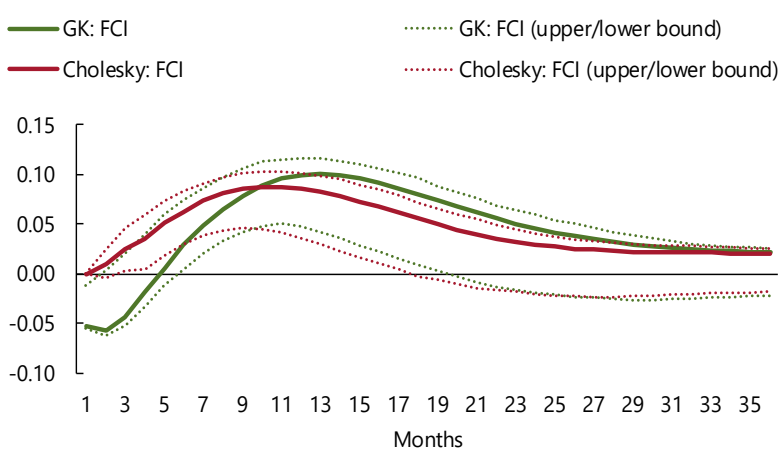

3. Norway

GK: $\mathrm{FCl}$
Cholesky: FCl

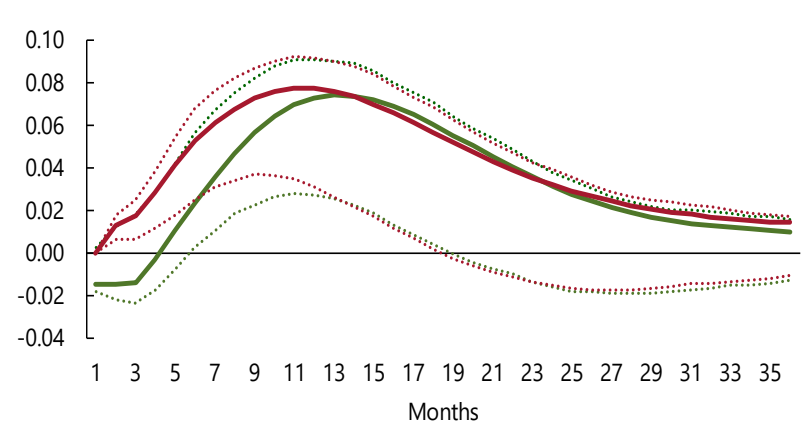

2. New Zealand
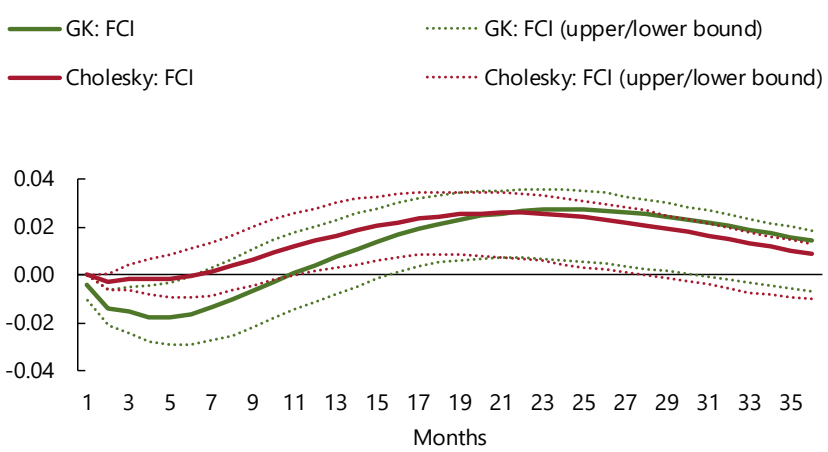

4. Sweden
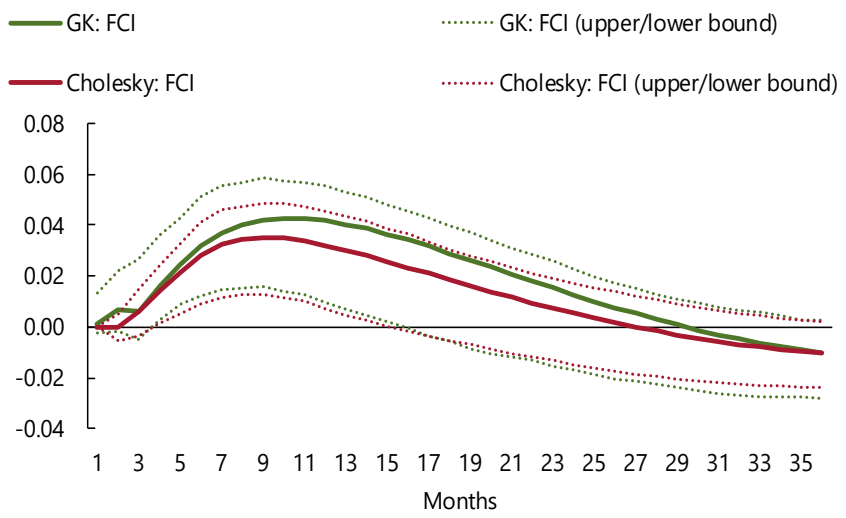

Sources: IMF, Global Data Source database, and authors' estimates.

Note: The figure displays the impulse response functions and their 90 percent confidence bands of domestic FCls to domestic monetary policy shocks for countries using two complementary methods to identify the monetary policy shocks. $\mathrm{GK}=$ Gertler and Karadi.

\section{E. The Influence of Global Financial Conditions: 2001-07 versus 2010-16}

Notably, there does not appear to be any discernible change in the importance of global financial conditions in influencing local FCIs over time. The cross-country exercises using the panel VAR models are repeated over the period before (2001-07) and after (2010-16) the global financial crisis to gauge how some of the relationships discussed above may have changed. The share of domestic financial conditions attributed to global financial conditions appears to be broadly stable over the two periods (Figure 13). In particular, the variance decompositions over 2001-07 and 2010-16 are not statistically different at the 95 percent level. 
Figure 13. Share of Domestic Financial Index Fluctuations Attributable to Global Financial Shocks Before and After the Global Financial Crisis

(In percent)

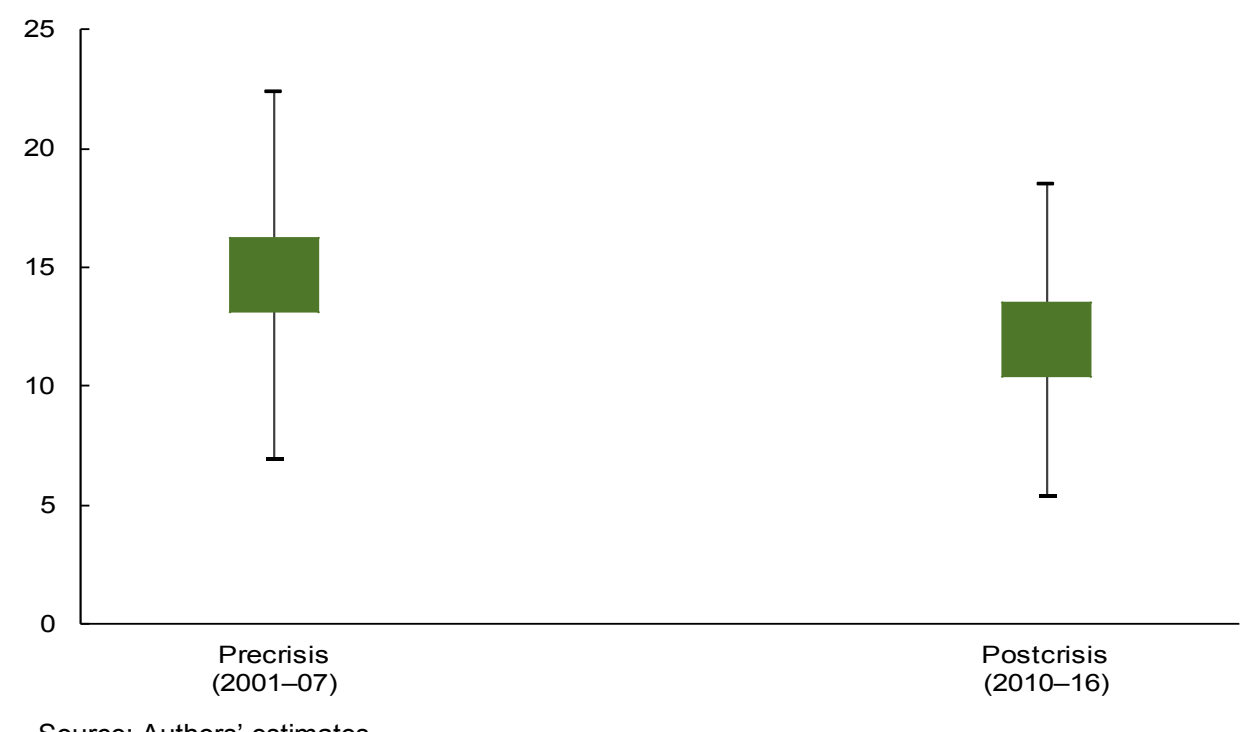

Source: Authors' estimates.

Note: The figure displays the share of domestic financial conditions index fluctuations attributable to global financial shocks (squares) for countries in the sample with flexible exchange rates based on the panel vector autoregression model for the pre-crisis (2001-07) and post-crisis (2010-16) samples, along with the 90 percent confidence bands (lines). See text for details.

\section{Conclusion}

This study finds that a single factor summarizes the dynamics of a significant share of financial conditions around the world well: global financial conditions, which move in tandem with the FCI of the U.S. and standard measures of global risk such as the VIX. However, the fraction of fluctuations in countries' domestic financial conditions attributed to global financial conditions does not appear to have increased markedly over the past two decades. Stronger financial linkages with the U.S. increase the sensitivity of domestic financial conditions to global financial shocks, and financial development attenuates it.

Despite the significant influence of global financial conditions, the analysis indicates that countries, on average, are still able to steer their domestic financial conditions to a significant extent. However, because domestic financial conditions respond faster and more strongly to global financial shocks than to changes in the domestic monetary policy stance, implementing timely and effective policy reactions may often be challenging.

In terms of future research, exploring asymmetries and threshold effects could yield fruitful insights. Do countries financial conditions react differently to a tightening compared to a loosening of global financial conditions? Are temporary, but acute, episodes of global tightening more influential for countries' FCIs than protracted period of accommodative global financial conditions?

Similarly, further explorations of the channels through which financial conditions get transmitted across countries, including the role played by different types of financial intermediaries, remain warranted. 


\section{Appendix}

\section{Table 1. Country Coverage}

\begin{tabular}{lllll}
\hline Argentina & Czech Republic & Israel & Philippines & United Kingdom \\
Australia & Denmark & Italy & Poland & United States \\
Austria & Finland & Japan & Portugal & Vietnam \\
Belgium & France & Korea & Russia & \\
Brazil & Germany & Malaysia & South Africa & \\
Bulgaria & Greece & Mexico & Spain & \\
Canada & Hungary & Netherlands & Sweden & \\
Chile & India & New Zealand & Switzerland & \\
China & Indonesia & Norway & Thailand & \\
\hline
\end{tabular}




\section{Table 2. Data Sources}

\begin{tabular}{|c|c|c|}
\hline Variables & Description & Source \\
\hline \multicolumn{3}{|l|}{ Domestic-Level Variables } \\
\hline Term Spreads & $\begin{array}{l}\text { Yield on } 10 \text {-year government bonds minus yield on three-month } \\
\text { treasury bills }\end{array}$ & Bloomberg Finance L.P.; IMF staff \\
\hline Interbank Spreads & Interbank interest rate minus yield on three-month treasury bills & Bloomberg Finance L.P.; IMF staff \\
\hline Change in Long Term Real Interest Rate & $\begin{array}{l}\text { Percentage point change in the } 10 \text {-year government bond yield, } \\
\text { adjusted for inflation }\end{array}$ & Bloomberg Finance L.P.; IMF staff \\
\hline Domestic Policy Rates & Policy-related interest rate of the country & Bloomberg Finance L.P.; Haver Analytics \\
\hline Corporate Spreads & $\begin{array}{l}\text { Corporate yield of the country minus corporate yield of the } \\
\text { benchmark country. JPMorgan CEMBI Broad is used for emerging } \\
\text { market economies where available. }\end{array}$ & $\begin{array}{l}\text { Bloomberg Finance L.P.; Thomson Reuters } \\
\text { Datastream }\end{array}$ \\
\hline Equity Returns (local currency) & Log difference of the equity indices & Bloomberg Finance L.P. \\
\hline House Price Returns & Percent change in house price index & Bank for International Settlements; IMF staff \\
\hline Equity Return Volatility & Exponential weighted moving average of equity price returns & Bloomberg Finance L.P.; IMF staff \\
\hline Change in Financial Sector Share & $\begin{array}{l}\text { Percentage point change in market capitalization of the financial } \\
\text { sector to total market capitalization }\end{array}$ & Bloomberg Finance L.P. \\
\hline Credit Growth & $\begin{array}{l}\text { Percent change in the depository corporations' claims on private } \\
\text { sector }\end{array}$ & $\begin{array}{l}\text { Haver Analytics; IMF, International Financial } \\
\text { Statistics database }\end{array}$ \\
\hline Sovereign Spreads & $\begin{array}{l}\text { Yield on 10-year government bonds minus the benchmark country's } \\
\text { yield on 10-year government bonds }\end{array}$ & Bloomberg Finance L.P.; IMF staff \\
\hline Real GDP Growth & Percent change in the GDP at constant prices & IMF, World Economic Outlook database \\
\hline Industrial Production Growth & Percent change in the industrial production index & $\begin{array}{l}\text { Haver Analytics; IMF, Global Data Source } \\
\text { database }\end{array}$ \\
\hline Inflation & Percent change in the consumer price index & $\begin{array}{l}\text { Haver Analytics; IMF, International Financial } \\
\text { Statistics database }\end{array}$ \\
\hline Current Account Balance & Current account balance to GDP & IMF, World Economic Outlook database \\
\hline Commodity Price Growth & Bloomberg commodity price index & Bloomberg Finance L.P. \\
\hline FDI Linkages with the U.S. & $\begin{array}{l}\text { Stock of bilateral direct investment position with the United States } \\
\text { to GDP }\end{array}$ & IMF, Coordinated Direct Investment Survey \\
\hline Portfolio Linkages with the U.S. & $\begin{array}{l}\text { Stock of bilateral portfolio investment position with the United } \\
\text { States to GDP; Source II: previous year's average of total flows } \\
\text { (purchases plus sales) of foreign securities between U.S. investors } \\
\text { and domestic investors (TIC data) to GDP }\end{array}$ & $\begin{array}{l}\text { IMF, Coordinated Portfolio Investment Survey; } \\
\text { Source II: U.S. Department of the Treasury }\end{array}$ \\
\hline Banking Linkages with the U.S. & $\begin{array}{l}\text { Bilateral BIS locational claims (residency basis) of the United States } \\
\text { to GDP }\end{array}$ & Bank for International Settlements \\
\hline Trade Linkages with the U.S. & Bilateral imports into the United States to GDP & IMF, Direction of Trade Statistics database \\
\hline Trade Openness & Exports plus imports to GDP & $\begin{array}{l}\text { IMF, Direction of Trade Statistics database; } \\
\text { IMF, World Economic Outlook database }\end{array}$ \\
\hline Financial Openness & Foreign assets plus foreign liabilities to GDP & $\begin{array}{l}\text { Lane and Milesi-Ferreti data set }(2007 ; \\
\text { updated) }\end{array}$ \\
\hline Capital Account Openness & $\begin{array}{l}\text { Chinn-Ito index measures a country's degree of capital account } \\
\text { openness }\end{array}$ & Chinn and Ito data set (2006; updated) \\
\hline Exchange Rate Stability & $\begin{array}{l}\text { Annual standard deviations of the monthly exchange rate between } \\
\text { the home country and the base country }\end{array}$ & $\begin{array}{l}\text { Aizenman, Chinn, and Ito data set (2010; } \\
\text { updated) }\end{array}$ \\
\hline Exchange Rate Flexibility & Degree of exchange rate flexibility & Ilzetzki, Reinhart, and Rogoff data set (2010) \\
\hline Financial Development & $\begin{array}{l}\text { Based on financial institutions' and markets' access, efficiency, and } \\
\text { depth }\end{array}$ & Sahay and others (2015) \\
\hline Rule of Law & $\begin{array}{l}\text { Reflects perceptions on the quality of contract enforcement, } \\
\text { property rights, the police, the courts, and the likelihood of crime } \\
\text { and violence }\end{array}$ & $\begin{array}{l}\text { World Bank, World Governance Indicators } \\
\text { database }\end{array}$ \\
\hline \multicolumn{3}{|l|}{ Global-Level Variables } \\
\hline VIX & Chicago Board Options Exchange Market Volatility Index & Bloomberg Finance L.P. \\
\hline Global Real GDP Growth & PPP-weighted average of real GDP growth & IMF, World Economic Outlook database \\
\hline Global Industrial Production Growth & PPP-weighted average of industrial production growth & IMF, Global Data Source database \\
\hline \multicolumn{3}{|l|}{ Variables used as Benchmarks } \\
\hline IMF Financial Stress Index & $\begin{array}{l}\text { Defined as a period during which the financial system of a country } \\
\text { is under strain and its ability to intermediate is impaired. The index } \\
\text { relies primarily on price movements relative to past levels or trends } \\
\text { to proxy for the presence of strains in financial markets and on } \\
\text { intermediation }\end{array}$ & $\begin{array}{l}\text { Cardarelli, Elekdag, and Lall data set (2009; } \\
\text { updated) accessed via IMF, Global Data } \\
\text { Source database }\end{array}$ \\
\hline Chicago Fed Financial Conditions Index & $\begin{array}{l}\text { Adjusted National Financial Conditions Index isolates a component } \\
\text { of financial conditions uncorrelated with economic conditions to } \\
\text { provide an update on the U.S. financial conditions relative to current } \\
\text { economic conditions }\end{array}$ & Federal Reserve Bank of Chicago \\
\hline Kansas City Fed Financial Stress Index & $\begin{array}{l}\text { A measure of stress in the U.S. financial system based on } 11 \\
\text { financial market variables }\end{array}$ & Federal Reserve Bank of Kansas City \\
\hline
\end{tabular}

Note: $\mathrm{BIS}=$ Bank for International Settlements; $\mathrm{CEMBI}=$ Corporate Emerging Markets Bond Index; FDI = foreign direct investment; PPP = purchasing power parity; TIC = Treasury International Capital; VIX = Chicago Board Options Exchange Volatility Index.

\section{CInternational Monetary Fund. Not for Redistribution}




\section{References}

Adrian, Tobias, and Nina Boyarchenko, 2012, "Intermediary Leverage Cycles and Financial Stability," Working Paper 2012-010, Becker Friedman Institute for Research in Economics, Chicago, IL.

— and Domenico Giannone, 2016, "Vulnerable Growth," Discussion Paper DP11583, Centre for Economic Policy Research, London.

Adrian, Tobias, and Nellie Liang, 2016, "Monetary Policy, Financial Conditions, and Financial Stability," Federal Reserve Bank of New York Staff Report 690.

Adrian, Tobias, and Hyun Song Shin, 2011, "Financial Intermediary Balance Sheet Management," Annual Review of Financial Economics 3 (1): 289-307.

Adrian, Tobias, Daniel Stackman, and Erik Vogt, 2016, "Global Price of Risk and Stabilization Policies,” Federal Reserve Bank of New York Staff Report 786.

Aizenman, Joshua, Menzie Chinn, and Hiro Ito, 2015, "Monetary Policy Spillovers and the Trilemma in the New Normal: Periphery Country Sensitivity to Core Country Conditions," NBER Working Paper 21128, National Bureau of Economic Research, Cambridge, MA.

Alfaro, Laura, Sebnem Kalemli-Ozcan, and Vadym Volosovych, 2008, "Why Doesn't Capital Flow from Rich to Poor Countries? An Empirical Investigation," Review of Economics and Statistics 90 (2): 347-68.

Balakrishnan, Ravi, Stephan Danninger, Selim Elekdag, and Irina Tytell, 2009, "The Transmission of Financial Stress from Advanced to Emerging Economies," IMF Working Paper 09/133, International Monetary Fund, Washington, DC.

Baskaya, Yusuf Soner, Julian di Giovanni, Sebnem Kalemli-Ozcan, and Mehmet Fatih Ulu, 2017, "International Spillovers and Local Credit Cycles," CEPR Discussion Paper 11839, Centre for Economic Policy Research, London.

Beaton, Kimberly, René Lalonde, and Corinne Luu, 2009, “A Financial Conditions Index for the United States," Discussion Paper 2009-11, Bank of Canada, Ottawa.

Bekaert, Geert, Campbell R. Harvey, Andrea Kiguel, and Xiaozheng Sandra Wang, 2016, “Globalization and Asset Prices," Annual Review of Financial Economics 8: 221-288.

Bernanke, Ben S. 2007, "The Financial Accelerator and the Credit Channel," Remarks at the Conference on The Credit Channel of Monetary Policy in the Twenty-First Century, Federal Reserve Bank of Atlanta, Atlanta, GA, June 15.

— , and Mark Gertler, 1989, "Agency Costs, Net Worth, and Business Fluctuations," American Economic Review 79 (1): 14-31. 
Boivin, Jean, Michael T. Kiley, and Frederic S. Mishkin, 2010, "How Has the Monetary Transmission Mechanism Evolved Over Time?” NBER Working Paper 15879, National Bureau of Economic Research, Cambridge, MA.

Boivin, Jean, and Serena Ng, 2006, “Are More Data Always Better for Factor Analysis?" Journal of Econometrics 132 (1): 169-94.

Bowman, David, Juan M. Londono, and Horacio Sapriza, 2015, "US Unconventional Monetary Policy and Transmission to Emerging Market Economies," Journal of International Money and Finance 55: 27-59.

Brandão-Marques, Luis, Gaston Gelos, and Natalia Melgar, 2013, “Country Transparency and the Global Transmission of Financial Shocks," IMF Working Paper 13/156, International Monetary Fund, Washington, DC.

Brandão-Marques, Luis, and Esther Perez-Ruiz Forthcoming, "Financial Conditions and Economic Activity in Latin America," International Monetary Fund, Washington, DC.

Brave, Scott, and R. Andrew Butters, 2011, "Monitoring Financial Stability: A Financial Conditions Index Approach,” Federal Reserve Bank of Chicago, Economic Perspectives (1Q/2011).

Bruno, Valentina, and Hyun Song Shin, 2013, "Global Factors in Capital Flows and Credit Growth," Working Paper 237, Griswold Center for Economic Policy Studies, Princeton University, Princeton, NJ.

Calvo, Guillermo A., Leonardo Leiderman, and Carmen M. Reinhart, 1996, "Inflows of Capital to Developing Countries in the 1990s," Journal of Economic Perspectives 10 (2): 123-39.

Cardarelli, Roberto, Selim Elekdag, and Subir Lall, 2011, "Financial Stress and Economic Contractions," Journal of Financial Stability 7 (2): 78-97.

Carlson, Mark A., Kurt F. Lewis, and William R. Nelson. 2012, "Using Policy Intervention to Identify Financial Stress," Finance and Economics Discussion Series Working Paper 2012-02, Board of Governors of the Federal Reserve System, Washington, DC.

Carrieri, Francesca, Ines Chaieb, and Vihang Errunza, 2013, "Do Implicit Barriers Matter for Globalization?" Review of Financial Studies 26 (7): 1694-739.

Chinn, Menzie D., and Hiro Ito. 2007, "Current Account Balances, Financial Development and Institutions: Assaying the World 'Saving Glut," Journal of International Money and Finance 26 (4): 546-69.

Dattels, Peter, Rebecca McCaughrin, Ken Miyajima, and Jaume Puig, 2010, "Can You Map Global Financial Stability?” IMF Working Paper 10/145, International Monetary Fund, Washington, DC. 
Davis, E. Philip, Simon Kirby, and James Warren, 2016, "The Estimation of Financial Conditions Indices for the Major OECD Countries," OECD Economics Department Working Paper 1335, Organization for Economic Co-operation and Development, Paris.

Disyatat, Piti, and Phurichai Rungcharoenkitkul, 2016, "Financial Globalisation and Monetary Independence,” BIS Paper 88, Bank for International Settlements, Basel.

Doz, Catherine, Domenico Giannone, and Lucrezia Reichlin, 2011, “A Two-Step Estimator for Large Approximate Dynamic Factor Models Based on Kalman Filtering," Journal of Econometrics 164: 188-205.

Dudley, William C. 2010, "Comments: Financial Conditions Indexes: A Fresh Look after the Financial Crisis," Remarks at the University of Chicago Booth School of Business Annual U.S. Monetary Policy Forum, New York, February 26.

, and Jan Hatzius, 2000, “The Goldman Sachs Financial Conditions Index: The Right Tool for a New Monetary Policy Regime," Global Economics Paper 44, Goldman Sachs, New York.

Forbes, Kristin J., and Menzie D. Chinn, 2004, "A Decomposition of Global Linkages in Financial Markets Over Time," Review of Economics and Statistics 86 (3): 705-22.

Forbes, Kristin J., and Roberto Rigobon, 2002, "No Contagion, Only Interdependence: Measuring Stock Market Comovements," Journal of Finance 57 (5): 2223-61.

Fratzscher, Marcel, 2012, "Capital Flows, Push Versus Pull Factors and the Global Financial Crisis," Journal of International Economics 88 (2): 341-56.

Freedman, Charles, 1994, "The Use of Indicators and of the Monetary Conditions Index in Canada." In Frameworks for Monetary Stability: Policy Issues and Country Experiences, edited by Tomas J. T. Balino and Carlo Cottarelli. Washington, DC: International Monetary Fund, 458-76.

Gauthier, Celine, Christopher Graham, and Ying Liu, 2004, "Financial Conditions Indexes for Canada," Working Paper 22, Bank of Canada, Ottawa.

Gertler, Mark, and Peter Karadi, 2015, "Monetary Policy Surprises, Credit Costs, and Economic Activity,” American Economic Journal: Macroeconomics 7 (1): 44-76.

Gilbert, Paul D., and Erik Meijer, 2005, “Time Series Factor Analysis with an Application to Measuring Money," Working Paper, University of Groningen.

Gilchrist, Simon, and Egon Zakrajšek, 2012, "Credit Spreads and Business Cycle Fluctuations," American Economic Review 102 (4): 1692-720.

Goodhart, Charles, and Boris Hofmann, 2001, "Asset Prices, Financial Conditions, and the Transmission of Monetary Policy," Paper presented at Conference on Asset Prices, Exchange Rates, and Monetary Policy, Stanford University, Stanford, CA, March 3. 
Guichard, Stéphanie, David Haugh, and David Turner, 2009, "Quantifying the Effect of Financial Conditions in the Euro Area, Japan, United Kingdom and United States." OECD Economics Department Working Paper 677, Organization for Economic Co-operation and Development, Paris.

Gumata, Nombulelo, Nir Klein, and Eliphas Ndou, 2012, “A Financial Conditions Index for South Africa.” IMF Working Paper 12/196, International Monetary Fund, Washington, DC.

Gürkaynak, Refet S., Brian Sack, and Eric Swanson, 2005, "The Sensitivity of Long-Term Interest Rates to Economic News: Evidence and Implications for Macroeconomic Models." American Economic Review 95 (1): 425-36.

Hakkio, Craig S., and William R. Keeton, 2009, "Financial Stress: What Is It, How Can It Be Measured, and Why Does It Matter?” Federal Reserve Bank of Kansas City, Economic Review (2): 5.

Hatzius, Jan, Peter Hooper, Frederic S. Mishkin, Kermit L. Schoenholtz, and Mark M. Watson, 2010, "Financial Conditions Indexes: A Fresh Look after the Financial Crisis," NBER Working Paper 16150, National Bureau of Economic Research, Cambridge, MA.

Hollo, Daniel, Manfred Kremer, and Marco Lo Duca, 2012, "CISS-A Composite Indicator of Systemic Stress in the Financial System,” ECB Working Paper 1426, European Central Bank, Frankfurt.

Illing, Mark, and Ying Liu, 2003, “An Index of Financial Stress for Canada,” Working Paper 2003/14, Bank of Canada, Ottawa.

Ilzetzki, Ethan, Carmen M. Reinhart, and Kenneth S. Rogoff, 2017, "Exchange Rate Arrangements Entering the 21st Century: Which Anchor Will Hold?" NBER Working Paper 23134, National Bureau of Economic Research, Cambridge, MA.

International Monetary Fund (IMF), 2014a, "Global Liquidity-Issues for Surveillance," IMF Policy Paper, Washington, DC.

2014b, "How Do Changes in the Investor Base and Financial Deepening Affect Emerging Market Economies? Global Financial Stability Report, Chapter 2, April, International Monetary Fund, Washington, DC.

2017, “Are Countries Losing Control of Domestic Financial Conditions?” Global Financial Stability Report, Chapter 3, October, International Monetary Fund, Washington, DC.

IMF-FSB-BIS. 2016, "Elements of Effective Macroprudential Policies: Lessons from International Experience," Note to the G20, August, International Monetary Fund, Washington, DC. 
Kamin, Steven B, 2010, "Financial Globalization and Monetary Policy," International Finance Discussion Paper 1002, Federal Reserve Bank, Washington, DC.

Kara, A. Hakan, Pinar Ozlu, and Deren Unalmis, 2012, "Financial Conditions Indices for the Turkish Economy," CBT Research Notes in Economics 1231, Central Bank of the Republic of Turkey, Ankara.

Kearns, Jonathan, and Nikhil Patel, 2016, "Does the Financial Channel of Exchange Rates Offset the Trade Channel?" BIS Quarterly Review (December), Bank for International Settlements, Basel.

Kennedy, Mike, and Angel Palerm, 2014, "Emerging Market Bond Spreads: The Role of Global and Domestic Factors from 2002 to 2011." Journal of International Money and Finance 43: 70-87.

Kiyotaki, Nobuhiro, and John Moore, 1997, “Credit Cycles," Journal of Political Economy 105 (2): 211-48.

Klein, Michael W., and Jay C. Shambaugh, 2015, "Rounding the Corners of the Policy Trilemma: Sources of Monetary Policy Autonomy," American Economic Journal: Macroeconomics 7 (4): 33-66.

Kliesen, Kevin L., Michael T. Owyang, and E. Katarina Vermann, 2012, "Disentangling Diverse Measures: A Survey of Financial Stress Indexes," Federal Reserve Bank of St. Louis Review 94 (5): 369-97.

Koop, Gary, and Dimitris Korobilis, 2014, "A New Index of Financial Conditions," European Economic Review 71: 101-16.

Longstaff, Francis A., Jun Pan, Lasse H. Pedersen, and Kenneth J. Singleton, 2011, "How Sovereign Is Sovereign Credit Risk?" American Economic Journal: Macroeconomics 3 (2): $75-103$.

Matheson, Troy D, 2012, "Financial Conditions Indexes for the United States and Euro Area," Economics Letters 115 (3): 441-46.

Miranda-Agrippino, Silvia, and Hélène Rey, 2015, "World Asset Markets and the Global Financial Cycle," NBER Working Paper 21722, National Bureau of Economic Research, Cambridge, MA.

Moccero, Diego Nicolas, Matthieu Darracq Pariès, and Laurent Maurin, 2014, "Financial Conditions Index and Identification of Credit Supply Shocks for the Euro Area," International Finance 17 (3): 297-321.

Obstfeld, Maurice, 2015, "Trilemmas and Trade-Offs: Living with Financial Globalization." BIS Working Paper 480, Bank for International Settlements, Basel. 
Oet, Mikhail V., Ryan Eiben, Timothy Bianco, Dieter Gramlich, and Stephen J. Ong, 2011, "The Financial Stress Index: Identification of Systemic Risk Conditions." Federal Reserve Bank of Cleveland, Working Paper No. 11-30, Cleveland.

Obstfeld, Maurice, Jonathan D. Ostry, and Mahvash S. Qureshi, 2017, "A Tie That Binds: Revisiting the Trilemma in Emerging Market Economies," IMF Working Paper 17/130, International Monetary Fund, Washington DC.

Osorio, Carolina, D. Filiz Unsal, and Runchana Pongsaparn, 2011, “A Quantitative Assessment of Financial Conditions in Asia." IMF Working Paper 11/170, International Monetary Fund, Washington, DC.

Passari, Evgenia, and Hélène Rey, 2015, "Financial Flows and the International Monetary System," Economic Journal 125 (584): 675-98.

Pesaran, Hashem M., Yongcheol Shin, and Ron P. Smith, 1999, "Pooled Mean Group Estimation of Dynamic Heterogeneous Panels," Journal of the American Statistical Association 94 (446): 621-34.

Primiceri, Giorgio, 2005, "Time Varying Structural Vector Autoregressions and Monetary Policy." Review of Economic Studies 72: 821-52.

Rey, Hélène,2013, “Dilemma Not Trilemma, The Global Financial Cycle and Monetary Policy Independence," Paper presented at Global Dimensions of Unconventional Monetary Policy Symposium, Jackson Hole, WY, August 24.

2016, "International Channels of Transmission of Monetary Policy and the Mundellian Trilemma," IMF Economic Review 64 (1): 6-35.

Sahay, Ratna, Martin Čihák, Papa M. N'Diaye, Adolfo Barajas, Ran Bi, Diana Ayala, Yuan Gao, Annette Kyobe, Lam Nguyen, Christian Saborowski, Katsiaryna Svirydzenka, and Seyed Reza Yousefi, 2015, "Rethinking Financial Deepening: Stability and Growth in Emerging Markets," IMF Staff Discussion Note 15/08, International Monetary Fund, Washington, DC.

Schoenmaker, Dirk, 2013, “The Financial Trilemma,” Economic Letters 111 (1): 57-59.

Schüler, Yves Stephan, Paul Hiebert, and Tuomas A. Peltonen, 2016. "Coherent Financial Cycles for G-7 Countries: Why Extending Credit Can Be an Asset," https://ssrn.com/abstract=2539717 or http://dx.doi.org/10.2139/ssrn.2539717.

Sugihara, George, Robert May, Hao Ye, Chih-hao Hsieh, Ethan Deyle, Michael Fogarty, and Stephan Munch, 2012, "Detecting Causality in Complex Ecosystems." Science 338: 496-500.

Swiston, Andrew J, 2008, “A U.S. Financial Conditions Index: Putting Credit Where Credit Is Due,” IMF Working Paper 08/161, International Monetary Fund, Washington, DC. 
Van den Heuvel, Skander J, 2002, "Does Bank Capital Matter for Monetary Transmission?" Economic Policy Review 8 (1): 259-65.

Yellen, Janet L, 2016, "Current Conditions and the Outlook for the U.S. Economy," Speech at the World Affairs Council of Philadelphia, Philadelphia, PA, June 6. 